\title{
Modulation of Canonical Transient Receptor Potential Channel 1 in the Proliferation of Oligodendrocyte Precursor Cells by the Golli Products of the Myelin Basic Protein Gene
}

\author{
Pablo M. Paez, Daniel Fulton, Vilma Spreuer, Vance Handley, and Anthony T. Campagnoni ${ }^{\dagger}$ \\ Semel Institute for Neuroscience and Human Behavior, David Geffen School of Medicine, University of California at Los Angeles, Los Angeles, California 90095
}

Golli proteins, products of the myelin basic protein gene, function as a new type of modulator of intracellular $\mathrm{Ca}^{2+}$ levels in oligodendrocyte progenitor cells (OPCs). Because of this, they affect a number of $\mathrm{Ca}^{2+}$-dependent functions, such as OPC migration and process extension. To examine further the $\mathrm{Ca}^{2+}$ channels regulated by golli, we studied the store-operated $\mathrm{Ca}^{2+}$ channels (SOCCs) in OPCs and acute brain slice preparations from golli knock-out and golli-overexpressing mice. Our results showed that pharmacologically induced $\mathrm{Ca}^{2+}$ release from intracellular stores evoked a significant extracellular $\mathrm{Ca}^{2+}$ entry after store depletion in OPCs. They also indicated that, under these pharmacological conditions, golli promoted activation of $\mathrm{Ca}^{2+}$ influx by SOCCs in cultured OPCs as well as in tissue slices. The canonical transient receptor potential family of $\mathrm{Ca}^{2+}$ channels (TRPCs) has been postulated to be SOCC subunits in oligodendrocytes. Using a small interfering RNA knockdown approach, we provided direct evidence that TRPC1 is involved in store-operated $\mathrm{Ca}^{2+}$ influx in OPCs and that it is modulated by golli. Furthermore, our data indicated that golli is probably associated with TRPC1 at OPC processes. Additionally, we found that TRPC1 expression is essential for the effects of golli on OPC proliferation. In summary, our data indicate a key role for golli proteins in the regulation of TRPC-mediated $\mathrm{Ca}^{2+}$ influx, a finding that has profound consequences for the regulation of multiple biological processes in OPCs. More important, we have shown that extracellular $\mathrm{Ca}^{2+}$ uptake through TRPC1 is an essential component in the mechanism of OPC proliferation.

\section{Introduction}

The myelin basic protein (MBP) gene encodes two families of proteins: the classic MBP components of the myelin membrane and a second set of products, the golli MBPs, whose function is only beginning to be understood (Campagnoni et al., 1993; Pribyl et al., 1993). Like the classic forms in the CNS, expression of golli proteins is developmentally regulated (Campagnoni et al., 1993; Landry et al., 1996). It tends to be high during embryonic development and declines with age (Landry et al., 1996, 1998). In the nervous system, golli proteins are expressed in oligodendrocytes (OLs) and in specific subsets of neurons, although golli protein expression has also been reported in activated microglia, macrophages, and adult OL progenitors (Filipovic et al., 2002).

Previous work has shown golli to be an important regulator of OL development and myelination. Golli regulates oligodendrocyte progenitor cell (OPC) process extension and differentiation in vitro (Paez et al., 2009a,b), and studies of golli knock-out (KO) and golli-overexpressing (JOE) brains indicate this influence on

\footnotetext{
Received Aug. 23, 2010; revised Nov. 22, 2010; accepted Jan. 3, 2011.

This investigation was supported (in part) by National Multiple Sclerosis Society Postdoctoral Fellowship FG1723A1/1 (P.M.P.) and National Multiple Sclerosis Society Grant RG4205-A-8 (A.T.C.). This paper is dedicated to the memory of Celia W. Campagnoni.

'Deceased, June 17, 2010 .

Correspondence should be addressed to Pablo M. Paez, Semel Institute for Neuroscience and Human Behavior, David Geffen School of Medicine, University of California at Los Angeles, Neuroscience Research Building, 635 Charles Young Drive, Los Angeles, CA 90095-7332. E-mail: ppaez@mednet.ucla.edu.

DOI:10.1523/JNEUROSCI.4424-10.2011

Copyright $\odot 2011$ the authors $\quad 0270-6474 / 11 / 313625-13 \$ 15.00 / 0$
}

OPC development has important consequences for myelination in vivo (Jacobs et al., 2005, 2009). The golli KO animals exhibit widespread hypomyelination, with particularly striking myelin deficits in the visual and somatosensory cortices and the optic nerve. This hypomyelination has clear functional effects because these animals exhibit alterations in visual evoked potentials (Jacobs et al., 2005). JOE animals express multiple copies of the J37 golli isoform under the control of the classic MBP promoter. These animals present severe intention tremors between approximately postnatal day 15 (P15) and P50 and exhibit generalized hypomyelination in the brain (Martin et al., 2007; Jacobs et al., 2009). At later ages, the tremors abate and increased myelination is observed.

The cellular and molecular mechanisms governing the altered development of golli KO and JOE OPCs have been partially elucidated. Recent findings have clearly established that golli protein plays a critical role in regulating $\mathrm{Ca}^{2+}$ influx in OPCs (Paez et al., 2007, 2009a,b; Fulton et al., 2010).

Calcium influx can occur via a number of different mechanisms within the cell including the following: (1) ligand-operated $\mathrm{Ca}^{2+}$ channels (Simpson et al., 1997; Butt, 2006), (2) voltagegated $\mathrm{Ca}^{2+}$ channels (Paez et al., 2007), and (3) by the opening of store-operated $\mathrm{Ca}^{2+}$ channels (SOCCs) in the membrane in response to $\mathrm{Ca}^{2+}$ depletion in the endoplasmic reticulum (ER) (Belachew et al., 2000; Alberdi et al., 2005). There are a number of $\mathrm{Ca}^{2+}$-selective store-operated currents found in different cells (Parekh and Putney, 2005), indicating that multiple types of SOCCs probably exist. The transient receptor potential (TRP) 
superfamily consists of six subfamilies, including the TRPC subfamily (the "canonical" TRPs). TRPCs have been postulated to be SOCC subunits and are a heterogeneous family of $\mathrm{Ca}^{2+}$ channels (Zitt et al., 2002; Smyth et al., 2006; Liao et al., 2007). Expression of TRPCs has been described in nervous tissue (Putney, 1999; Riccio et al., 2002), but most storeoperated cation conductances have been demonstrated in excitable cells (Putney, 1993). Up to now, a role for TRPC channels in OLs has not been defined.

The goal of this study was to define the $\mathrm{Ca}^{2+}$ channels through which golli modulates $\mathrm{Ca}^{2+}$ homeostasis in OPCs and thereby modulates essential OPC functions, such as proliferation. In all the experiments, pharmacological tools and imaging techniques were used to compare the physiology of OPCs in genotype control mice to golli $\mathrm{KO}$ and golli-overexpressing (JOE) mice, both in vitro (cultured OPCs) and in situ (slice preparation). We show that changes in golli expression alter the activity of TRPC channels in OPCs, a finding that has profound consequences on multiple aspects of OPC maturation and survival.

\section{Materials and Methods}

Transgenic mice

Golli KO mouse. We previously generated a golli KO mouse in which the golli products of the MBP gene were selectively ablated while permitting normal expression of the classic MBPs (Jacobs et al., 2005). Through non-brother-sister crosses, a line was generated that is homozygous for the golli ablation on a background that is $50 \% 129 \mathrm{~S} 7 / \mathrm{SvEvBrd}$ and 50\% C57BL6/J. A control line (KO Control) was established that was also 50\% 129S7/ SvEvBrd and 50\% C57BL6/J but was negative for the golli ablation. The golli KO phenotype was observed before keeping the lines separate and then was studied over at least eight generations and remained stable.

JOE mouse. We generated a transgenic mouse that overexpresses the golli isoform J37 in oligodendrocytes under the control of a classic MBP promoter (Martin et al., 2007; Jacobs et al., 2009). In this transgenic mouse, the J37 golli isoform is driven by a $1.9 \mathrm{~kb}$ region of the classic MBP promoter, thus directing overexpression of the protein specifically to OLs in the CNS. These mice are called JOE mice for golli "J37 overexpressing." A line was generated that is heterozygous for the MBP 1.9-J37 transgene on a background that is $50 \% \mathrm{BALB} /$ cByJ, 37-50\% C57BL/6, and 0-12\% C3H/He. A control line (JOE Control) was established that was also $50 \%$ BALB/cByJ, $37-50 \%$ $\mathrm{C} 57 \mathrm{BL} / 6$, and $0-12 \% \mathrm{C} 3 \mathrm{H} / \mathrm{He}$.

\section{Primary cultures of}

cortical oligodendrocytes

Enriched oligodendrocytes were prepared as described by Amur-Umarjee et al. (1993). First, cerebral hemispheres from 1-d-old mice were mechanically dissociated and were plated on poly-D-lysine-coated flasks in DMEM and Ham's F-12 (1:1 v/v) (Invitrogen), containing $100 \mu \mathrm{g} / \mathrm{ml}$ gentamycin and supplemented with $4 \mathrm{mg} / \mathrm{ml}$ dextrose anhydrous, $3.75 \mathrm{mg} / \mathrm{ml}$ HEPES buffer, $2.4 \mathrm{mg} / \mathrm{ml}$ sodium bicarbonate, and $10 \%$ fetal bovine serum (FBS) (Omega Scientific). After $24 \mathrm{~h}$, the medium was changed and the cells were grown in DMEM/F-12 supplemented with insulin $(5 \mu \mathrm{g} / \mathrm{ml})$, transferrin
Table 1. Sequences of primers and PCR product sizes used in the semiquantitative RT-PCR

\begin{tabular}{|c|c|c|c|}
\hline Gene & Primer & Sequence & Size (bp) \\
\hline & Sense & 5'-CAAGATTTTGGGAAATTTCTGG-3' & 372 \\
\hline \multirow[t]{2}{*}{ TRPC1 } & Antisense & 5'-TTTATCCTCATGATTTGCTAT-3' & \\
\hline & Sense & 5'-CAGCTTCACCCGACTGGCATAT-3' & 487 \\
\hline \multirow[t]{2}{*}{ TRPC2 } & Antisense & 5'-CTTTGGGGATGGCAGGATGTTA-3' & \\
\hline & Sense & 5'-TGACTTCTGTTGTCCTCAAATATG-3' & 311 \\
\hline \multirow[t]{2}{*}{ TRPC3 } & Antisense & 5'-CAGTCTTCTCCTCCTGCATTT-3' & \\
\hline & Sense & 5'-TCTGCAGATATCTCTGGGAAGGATGC-3' & 415 \\
\hline \multirow[t]{2}{*}{ TRPC4 } & Antisense & 5'-AAGCTTTGTTCGAGCAAATTTCCATTC-3' & \\
\hline & Sense & $5^{\prime}$-ATCAGAACCGTGCCAAGAGCTA-3' & 449 \\
\hline \multirow[t]{2}{*}{ TRPC5 } & Antisense & 5'-CCCCATTTGTGCATGAGCAAGT-3' & \\
\hline & Sense & 5'-TTCATCATGGTGTTTGTAGCCTTT-3' & 300 \\
\hline TRPC6 & Antisense & 5'-CACGTCCGCATCATCCTCAATTTC-3' & \\
\hline
\end{tabular}

Table 2. Sequences of Stealth RNAi siRNA duplexes used for TRPC1 knockdown

\begin{tabular}{ll}
\hline & siRNA duplex oligoribonucleotide sequence \\
\hline siRNA1 & UUAACAUUAUCAGAGCUGGACUGGC \\
& GCCAGUCCAGCUCUGAUAAUGUUAA \\
siRNA2 & AAGAGUCGAAGGUACUCAGAACGU \\
& ACGUUCUGAGUUACCUUCGACUCUU \\
SiRNA3 & AUGAUUUGCUAUCAGCUGGAAGCUC \\
& GAGCUUCCAGCUGAUAGCAAUCAU \\
\hline
\end{tabular}

A
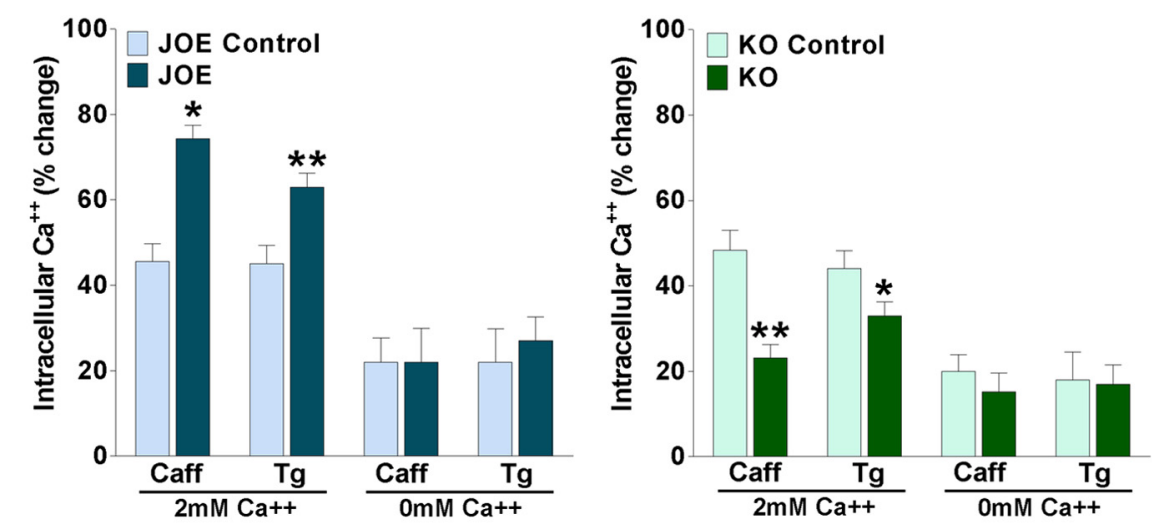

B
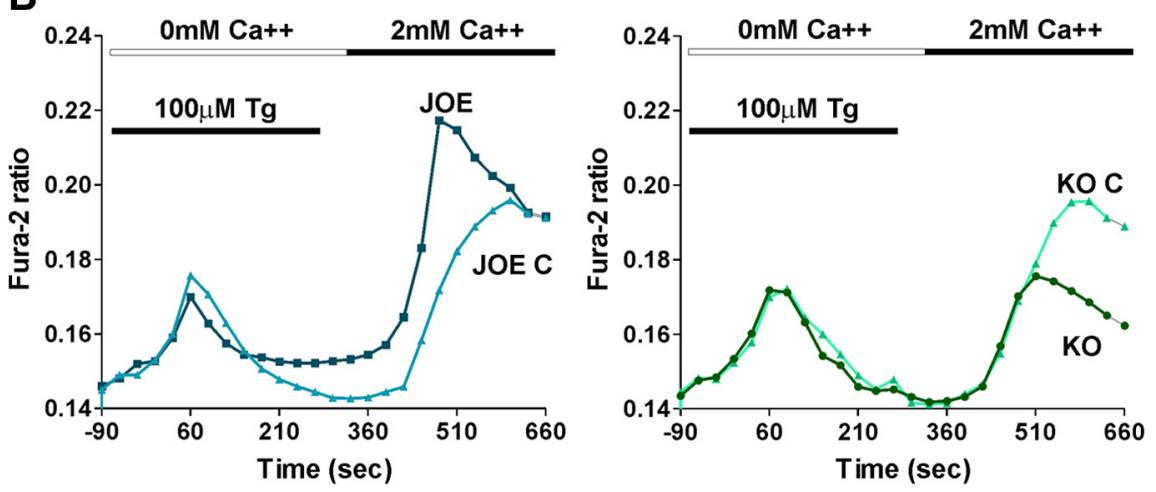

Figure 1. SOCC activity was examined in JOE and golli KO OPCS. A, Application of either caffeine (Caff) ( $2 \mathrm{~mm})$ or Tg (100 $\mu \mathrm{M})$ to JOE and golli KO OPCs elicited robust increases in the fura- 2 ratio that were dependent on the presence of external $\mathrm{Ca}^{2+}$. The graphs shows the average amplitude calculated from the responding cells, expressed as percentage of change of the emission intensities. Values are expressed as mean \pm SEM of at least four independent experiments ( $n>400$ cells for each condition). ${ }^{*} p<$ $0.05,{ }^{* *} p<0.01$ versus respective control. $\boldsymbol{B}$, Fura-2-loaded JOE and golli KO OPCs were first pretreated with Tg in the presence of zero $\mathrm{Ca}^{2+}$ medium and then reexposed to a $2 \mathrm{~mm} \mathrm{Ca}^{2+}$-containing medium to trigger $\mathrm{Ca}^{2+}$ influx via SOCC. Fura-2 ratios in selected cells are plotted with respect to the time of stimulation. The times of addition of $\mathrm{Tg}$ - and $\mathrm{Ca}^{2+}$-containing external solutions are indicated by the horizontal bars. 
A

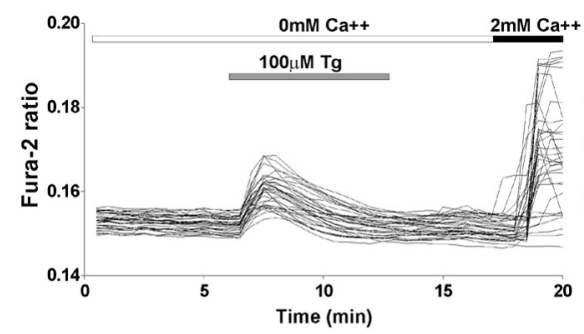

C

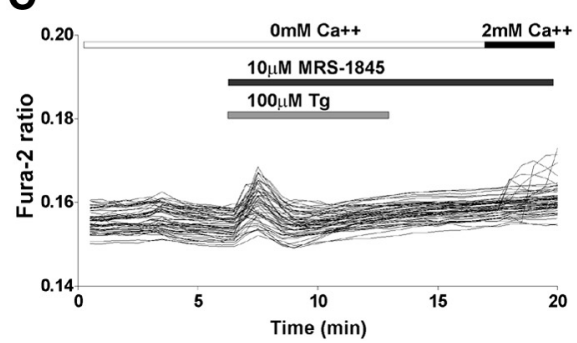

B

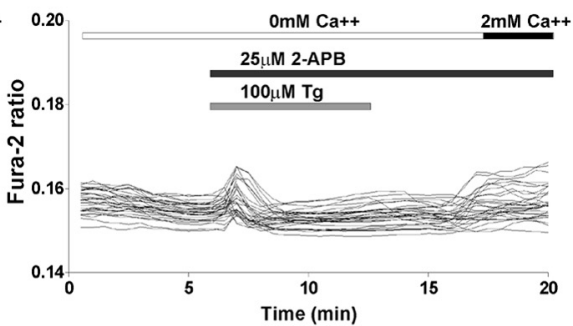

$D_{8}$

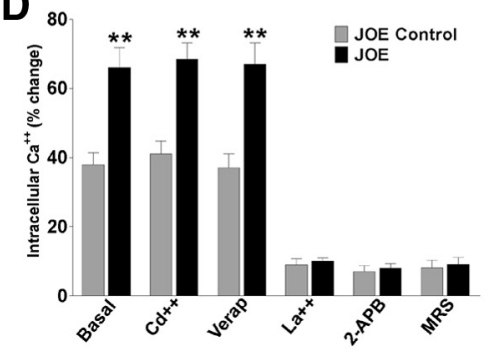

Figure 2. $\quad \boldsymbol{A}, \mathrm{SOCC}$ activity was examined in $\mathrm{OE} \mathrm{OPCS}$ pretreated with $\mathrm{Tg}$ in the presence of zero $\mathrm{Ca}^{2+}$ medium. $\boldsymbol{B}$, The increased $\mathrm{Ca}^{2+}$ response in JOE cells, after reexposure to $2 \mathrm{~mm} \mathrm{Ca}^{2+}$-containing medium, was totally abolished in $25 \mu \mathrm{M} 2$ 2-APB. C, Similar results were found using $10 \mu \mathrm{M}$ MRS-1845, a specific blocker of store-operated $\mathrm{Ca}^{2+}$ entry. Note that each trace corresponds to a single OPC. The times of addition of Tg-, 2-APB-, MRS-1845-, and $\mathrm{Ca}^{2+}$-containing external solutions are indicated by the horizontal bars. $\boldsymbol{D}$, The increased $\mathrm{Ca}^{2+}$ response in JOE cells was insensitive to treatment with $10 \mu \mathrm{m} \mathrm{Cd}^{2+}$ or $25 \mu \mathrm{m}$ verapamil and was abolished in $1 \mu \mathrm{m} \mathrm{La}^{2+}, 25 \mu \mathrm{M} 2-\mathrm{APB}$, and $10 \mu \mathrm{M}$ MRS-1845. The graphs show the average amplitude calculated from the responding cells, expressed as percentage of change of the emission intensities. Values are expressed as mean \pm SEM of at least four independent experiments ( $n>400$ cells for each condition). ${ }^{* *} p<0.01$ versus respective controls.

(50 $\mu \mathrm{g} / \mathrm{ml})$, sodium selenite (30 nм), $\mathrm{T}_{3}(15 \mathrm{~nm})$, D-biotin (10 mm), hydrocortisone (10 nM), 0.1\% BSA (Sigma), 1\% horse serum, and 1\% FBS (Omega Scientific). After 9 d, OPCs were purified from the mixed glial culture by the differential shaking and adhesion procedure by Suzumura et al. (1984) and allowed to grow on polylysine-coated coverslips in defined culture media (Agresti et al., 1996) plus PDGF $(10 \mathrm{ng} / \mathrm{ml})$ and basic fibroblast growth factor (bFGF) $(10 \mathrm{ng} / \mathrm{ml})$ (Peprotech).

\section{Immunocytochemistry}

Cells were stained with antibodies against golli, TRPC1, and phosphoHistone H3 (Ser10) and examined by confocal microscopy. For golli and phospho-Histone H3 (Ser10) immunostaining, the cells were rinsed briefly in PBS and fixed in 4\% buffered paraformaldehyde for $30 \mathrm{~min}$ at room temperature. After rinsing in PBS, the cells were permeabilized with $0.1 \%$ Triton X-100 in PBS for 10 min at room temperature and then processed for immunocytochemistry following the protocol as outlined by Reyes et al. (2002). Essentially, fixed cells were incubated in a blocking solution (5\% goat serum in PBS) followed by an overnight incubation at $4^{\circ} \mathrm{C}$ with a polyclonal antibody for golli (1:500) and phospho-Histone $\mathrm{H} 3$ (Ser10) (1:100; Millipore). Staining with TRPC1 (1:100; Alomone Labs) was performed on live cells without permeabilization for $1 \mathrm{~h}$ at room temperature before fixation. Cells were then incubated with the appropriate secondary antibodies (1:200; Jackson ImmunoResearch) and mounted onto slides with Aquamount (Lerner Laboratories), and fluorescent images were obtained using a Olympus spinning disc confocal microscope. Nuclei were stained with the fluorescent dye Hoechst 33342 ( $5 \mu \mathrm{g} / \mathrm{ml}$ in $1 \% \mathrm{DMSO}$ ), to determine the total number of cells. Quantitative analysis of the results was done counting the antigen-positive and Hoechst-positive cells in 20 randomly selected fields, which resulted in counts of $>2000$ cells for each experimental condition. Counts of antigen-positive cells were normalized to the counts of total Hoechstpositive cells for each condition.

\section{Western blot analysis}

Petri dishes containing $\sim 1.5 \times 10^{6}$ cells per dish, under the different experimental conditions, were washed twice with PBS. The cells were collected by centrifugation $\left(600 \times g\right.$ for $10 \mathrm{~min}$ at $\left.4^{\circ} \mathrm{C}\right)$ and extracted with $20 \mathrm{~mm}$ Tris- $\mathrm{HCl}, \mathrm{pH}$ 7.4, $150 \mathrm{~mm} \mathrm{NaCl}, 10 \mathrm{~mm}$ EDTA, and 0.5\% Triton
$\mathrm{X}-100$ for $1 \mathrm{~h}$ at $4^{\circ} \mathrm{C}$. The insoluble material was cleared out by centrifugation $(100,000 \times g$ for 20 $\min$ at $\left.4^{\circ} \mathrm{C}\right)$, and the resulting protein extracts $(50$ $\mu \mathrm{g} / \mathrm{lane})$ were subjected to SDS-PAGE $(12.5 \%$ gels). After transfer, samples were analyzed by Western blot using an specific antibody for TRPC1 (1:500; Alomone Labs). Antibody binding was visualized with horseradish peroxidaseconjugated secondary antibody (used at a 1:1000 dilution) and the ECL Plus substrate kit (GE Healthcare).

\section{Reverse transcription-PCR}

Total RNA was isolated from $35 \mathrm{~mm}$ cell culture dishes containing $\sim 1.5 \times 10^{6}$ cells per dish, using TRIZOL reagent (Invitrogen) according to the instructions of the manufacturer. RNA content was estimated by measuring the absorbance at $260 \mathrm{~nm}$, and the purity was assessed by measuring $A_{260} / A_{280}$ ratios. PCR primers for TRPC1TRPC6 were designed based on published sequences by Wang et al. (2004) with some modifications (Table 1). First-strand cDNA was prepared from $1 \mu \mathrm{g}$ of total RNA using SuperScript III RNase H-reverse transcriptase (Invitrogen) and $1 \mu \mathrm{g}$ of oligo-dT. The mRNA samples were denaturated at $65^{\circ} \mathrm{C}$ for $5 \mathrm{~min}$. Reverse transcription (RT) was performed at $50^{\circ} \mathrm{C}$ for $55 \mathrm{~min}$ and was stopped by heating samples at $85^{\circ} \mathrm{C}$ for $5 \mathrm{~min}$. The cDNA was amplified by PCR using the TRPC isoform-specific primers listed in Table 1 and PCR Platinum Supermix reagent (Invitrogen). PCR conditions were as follows: $94^{\circ} \mathrm{C}$ for $2 \mathrm{~min}$, 40 cycles of $94^{\circ} \mathrm{C}$ for $30 \mathrm{~s}, 58^{\circ} \mathrm{C}$ for $30 \mathrm{~s}$, followed by $68^{\circ} \mathrm{C}$ for $2 \mathrm{~min}$. After completion of the 40 cycles, samples were incubated at $72^{\circ} \mathrm{C}$ for $10 \mathrm{~min}$. A $\beta$-tubulin-positive control was performed alongside the experimental samples, as well as a negative control with no reverse transcriptase. The PCR products were visualized on an ethidium bromide-stained agarose gel, and the bands were digitized using a UVP BioImaging Analysis System with VisionWorksLS 5.5 software.

\section{Small interfering RNA knockdown of TRPC1}

OPCs were isolated and cultured in defined culture media (Agresti et al., 1996) plus PDGF (10 ng/ml) and bFGF (10 ng/ml). Twenty four hours after plating, the cells were transiently transfected with a combination of three different Stealth RNAi small interfering RNA (siRNA) duplexes (Invitrogen) specific for TRPC1 (for siRNA duplex sequences, see Table 2). Briefly, 6 pmol of each siRNA duplex were mixed with Lipofectamine RNAiMAX (Invitrogen), and the mixture was placed on $35 \mathrm{~mm}$ Petri dishes containing $80 \%$ confluent OPCs. OPCs were then further cultured for $48 \mathrm{~h}$ in defined culture media (Agresti et al., 1996) plus PDGF (10 $\mathrm{ng} / \mathrm{ml})$ and bFGF $(10 \mathrm{ng} / \mathrm{ml}$ ) before used for mRNA and protein determinations and $\mathrm{Ca}^{2+}$ imaging experiments. Control cells were exposed to Lipofectamine RNAiMAX alone using the same protocol.

\section{Incorporation of bromodeoxyuridine}

Twenty four hour pulses of $10 \mu \mathrm{M}$ bromodeoxyuridine (BrdU) (BD Biosciences Pharmingen) were performed under different experimental conditions. After each BrdU pulse, cells were fixed in $4 \%$ paraformaldehyde and immunostained to determine the number of positive cells. After treatment with $6 \mathrm{~N} \mathrm{HCl}$ and $1 \%$ Triton $\mathrm{X}-100$ to denature nuclear DNA, the cells were incubated in $0.1 \mathrm{~m}$ sodium borate (in PBS and $1 \%$ Triton X-100) for $10 \mathrm{~min}$. Immunocytochemistry was done using an anti-BrdU antibody (1:1000; BD Biosciences Pharmingen) and an anti-NG2 (1:100; Millipore Bioscience Research Reagents) with the corresponding fluorescent secondary antibodies. The percentage of BrdU-positive $\left(\mathrm{BrdU}^{+}\right)$cells was estimated on the basis of the total number of $\mathrm{NG}^{+}$cells. 

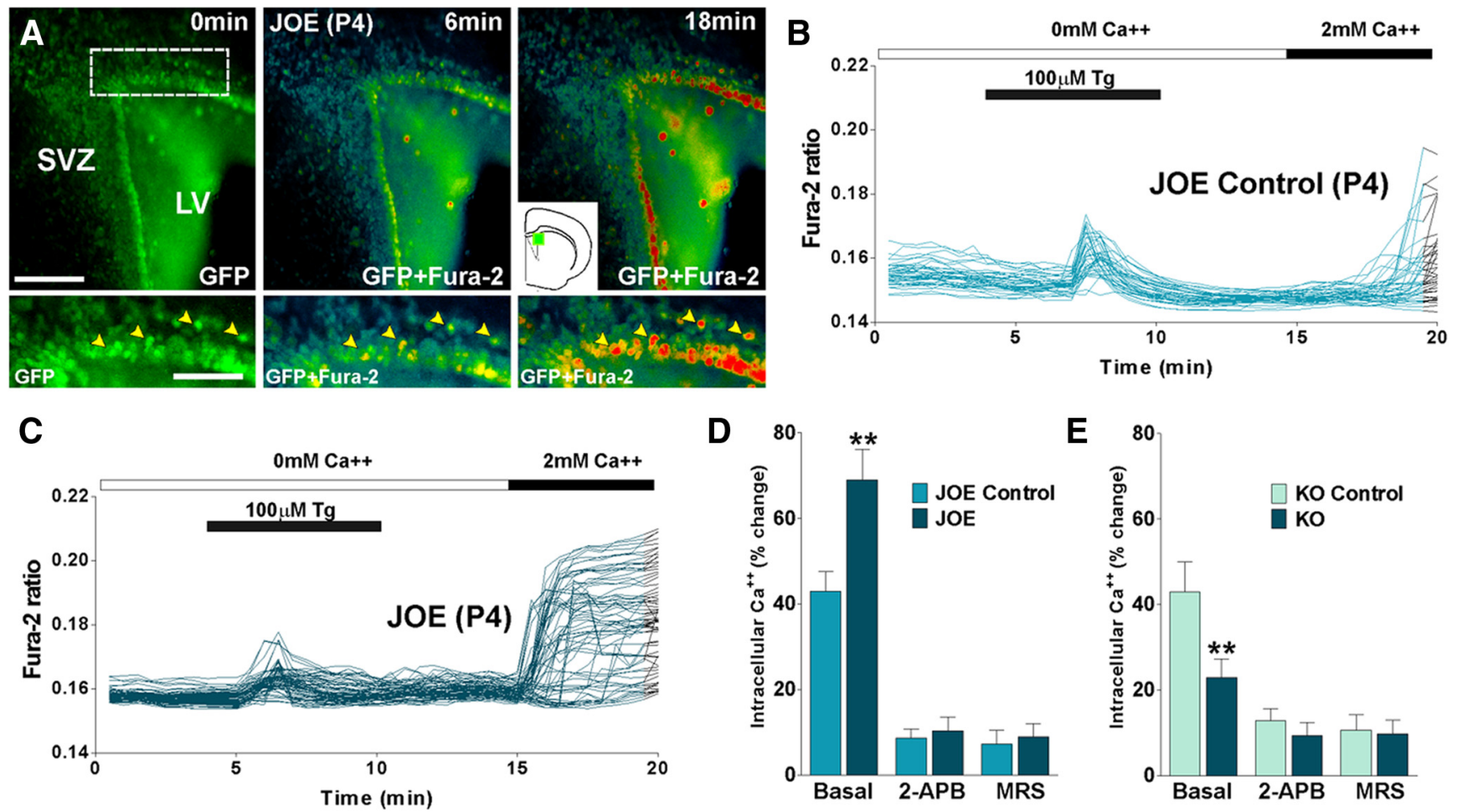

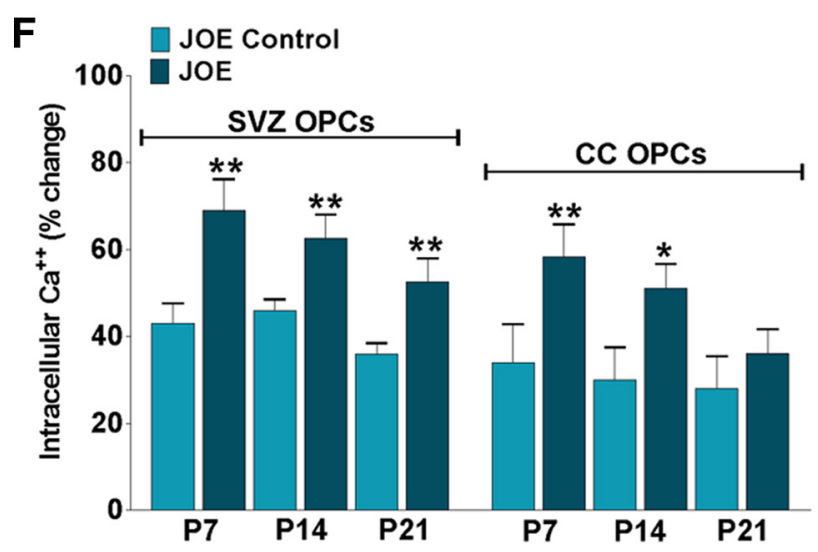

Figure 3. Brain slices were incubated in a chamber with $5 \% \mathrm{CO}_{2}$ at $37^{\circ} \mathrm{C}$, which was placed on the stage of a spinning disc confocal inverted microscope. Fura- 2 images were obtained for brain slices with specific filters at $5 \mathrm{~s}$ intervals for a total of $20 \mathrm{~min}$. A, Time-lapse series of P4 GFP-expressing OPCs in the dorsolateral SVZ. Each frame represents a single section of a fura-2 time-lapse experiment. An increased fura-2 fluorescence ratio is indicated by warmer colors. Time is denoted in minutes in the top right corner, and the area of the dorsolateral SVZ is indicated in the inset. LV, Lateral ventricle. Scale bar, $200 \mu \mathrm{m}$. Yellow arrowheads in high-magnification insets show OPCs that were selected for the analysis. Scale bar, $60 \mu \mathrm{m}$. B, C, SOCC activity was examined in P4 GFP-expressing OPCs from JOE control and JOE mice pretreated with $\mathrm{Tg}$ in the presence of zero $\mathrm{Ca}^{2+}$ medium. Note that each trace corresponds to a single cell, and times of Tg and $\mathrm{Ca}^{2+}$ addition are indicated by the horizontal bars. D, E, The $\mathrm{Ca}^{2+}$ response in SVZ JOE and golli KO cells after reexposure to $\mathrm{Ca}^{2+}$-containing medium was totally abolished in $25 \mu \mathrm{m} 2$-APB and $10 \mu \mathrm{M}$ MRS-1845. F, SOCC activity was examined in GFP-expressing OPCs from the SVZ and corpus callosum (CC) of control and JOE mice at P7, P14, and P21. The graphs show the average amplitude calculated from the responding cells expressed as percentage of change of the emission intensities. Values are expressed as mean \pm SEM of at least four independent experiments ( $n>200$ cells for each condition). ${ }^{* *} p<0.01$ versus respective controls.

\section{Cell cycle time analysis}

To examine cell cycle time (Tc), mixed glial culture of green fluorescent protein (GFP)-labeled OPCs were used. These experiments were performed using a double-transgenic mouse created by breeding the JOE mouse with a line expressing GFP under control of the proteolipid protein (PLP) promoter (Mallon et al., 2002). Mixed glial cultures were prepared as described above (see Primary cultures of cortical oligodendrocytes). These cultures were incubated in a stage top chamber with $5 \%$ $\mathrm{CO}_{2}$ at $37^{\circ} \mathrm{C}$, which was placed on the stage of a spinning disc confocal inverted microscope equipped with a motorized stage, an atmosphere regulator, and shutter control. Fluorescent field images were obtained with a specific GFP filter at 6 min intervals. Individual clones of OPCGFP were followed for a period of $48 \mathrm{~h}$ beginning at 4 and $6 \mathrm{~d}$ in vitro
(DIV) before the shake off. In these time-lapse experiments, $\sim 30$ clones were analyzed per experimental condition.

SlideBook 4.1 (Intelligent Imaging Innovations) was used in the analysis of video microscopic image sequences. The SlideBook software allow an investigator to cycle back-and-forth through the movie files frame by frame (minute by minute), facilitating the accurate determination of event time. To quantitatively analyze the dynamics of cell division, 120 cytokinetic events were randomly selected from movies at 4 and 6 DIV. Cell proliferation was assessed by calculating the average Tc (time between birth cytokinesis and division cytokinesis) in different OPC-GFP clones. Tracking of cells was performed by visual observation of image sequences as described above. In some cases, the cells were semiautomatically followed in SlideBook by attaching a number to the cell, which was 
A

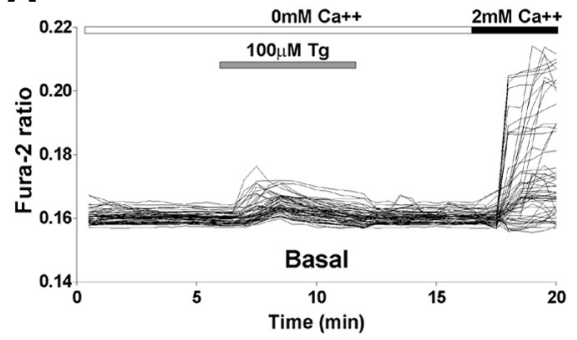

C

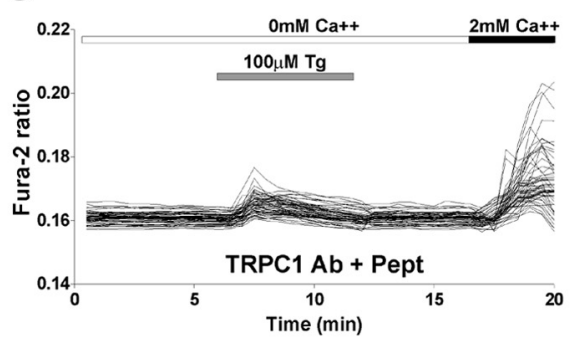

B

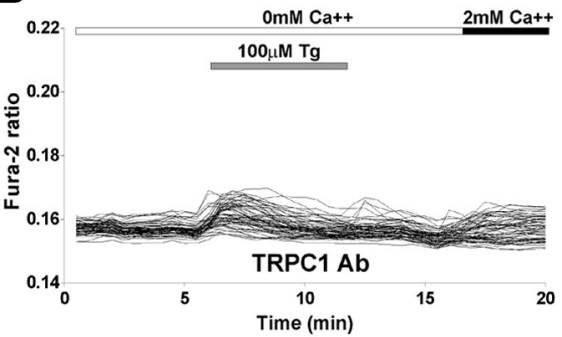

D

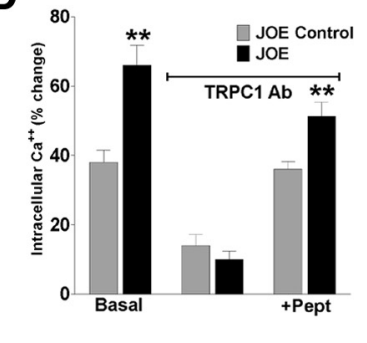

Figure 4. $\quad \boldsymbol{A}$, SOCC activity was examined in JOE OPCS pretreated with $\mathrm{Tg}$ in the presence of zero $\mathrm{Ca}^{2+}$ medium (Basal). $\boldsymbol{B}, \mathrm{JOE}$ OPCs were incubated with an antibody against TRPC1 $(10 \mu \mathrm{g} / \mathrm{ml} ; 1 \mathrm{~h})$ before depleting their internal $\mathrm{Ca}^{2+}$ stores with $\mathrm{Tg}$ in zero $\mathrm{Ca}^{2+}$ solution (TRPC1 Ab). Compared with JOE cells in basal conditions $(\boldsymbol{A})$, these OPCs have a significant decrease in internal $\mathrm{Ca}^{2+}$ elevations when $2 \mathrm{~mm} \mathrm{Ca}^{2+}$ is returned to the external solution. $C$, The effect of anti-TRPC1 was totally abolished by preincubation of the antibody with the antigen peptide (+Pept). The times of addition of $\mathrm{Tg}$ - and $\mathrm{Ca}^{2+}$-containing external solutions are indicated by the horizontal bars. $\boldsymbol{D}$, The graphs show the average amplitude calculated from the responding cells, expressed as percentage of change of the emission intensities for each experimental condition. Values are expressed as mean \pm SEM of at least four independent experiments ( $n>400$ cells for each condition). ${ }^{* *} p<0.01$ versus respective controls.

propagated from frame to frame. Tracking was performed forward and backward in time from each identified cytokinesis events to maximize the number of lineally related cytokineses identified.

\section{Slice preparation}

Calcium imaging acquisitions of GFP-labeled OPCs were performed on living slices cut in coronal orientation at P4, as described previously (Kakita and Goldman, 1999). Briefly, mice were anesthetized with isoflurane, after which brains were rapidly removed and stored in ice-cold bicarbonate-buffered solution gassed with $95 \% \mathrm{O}_{2}$ and $5 \% \mathrm{CO}_{2}$ (Fulton et al., 2010). Coronal and sagittal slices were cut at $300 \mu \mathrm{m}$ thickness on a vibratome. Brain tissue was kept in ice-cold bicarbonate solution during these procedures. The slices were then cultured with Eagle's Basal Medium with Earle's salts (Invitrogen) supplemented with $18.6 \mathrm{~mm} \mathrm{NaHCO}_{3}, 1 \%$ BSA (fraction 5; Sigma), $5 \mu \mathrm{g} / \mathrm{ml}$ insulin, $5 \mu \mathrm{g} / \mathrm{ml}$ transferrin, $5 \mu \mathrm{g} / \mathrm{ml}$ sodium selenite (Sigma), $20 \mathrm{U} / \mathrm{ml}$ penicillin-streptomycin (Invitrogen), $2 \mathrm{~mm}$ L-glutamine (Invitrogen), and $27 \mathrm{~mm}$ glucose. After this, brain slices were ready for calcium imaging studies.

\section{Calcium imaging}

Methods were similar to those described previously (Colwell, 2000; Michel et al., 2002; Paz Soldan et al., 2003). Briefly, a cooled CCD camera (Hamamatsu ORCA-ER) was added to the Olympus spinning disc confocal microscope to measure fluorescence. To load the dye into cells, primary cultures of oligodendrocytes and brain slices were washed in serum and phenol red-free DMEM and incubated for $45 \mathrm{~min}$ at $37^{\circ} \mathrm{C}, 5 \%$ $\mathrm{CO}_{2}$ in the same media containing a final concentration of $4 \mu \mathrm{M}$ fura-2 AM (TefLabs) plus $0.08 \%$ Pluronic F-127 (Invitrogen), then washed four times in DMEM, and stored in DMEM for $0-1 \mathrm{~h}$ before being imaged (Paz Soldan et al., 2003). Resting calcium levels were made in serum-free HBSS containing $2 \mathrm{mM} \mathrm{Ca}^{2+}$ but no $\mathrm{Mg}^{2+}$. Other measurements were made in HBSS. Calcium influx and resting $\mathrm{Ca}^{2+}$ levels were measured on individual cells, and the results were pooled from five separate cells preparations for each condition. The fluorescence of fura- 2 was excited alternatively at wavelengths of 340 and $380 \mathrm{~nm}$ by means of a high-speed wavelength-switching device (Lambda DG-4; Sutter Instruments). Image analysis software (SlideBook 4.1; Intelligent Imaging Innovations) allowed the selection of several "regions of interest" within the field from which measurements are taken. To minimize bleaching, the intensity of excitation light and sampling frequency was kept as low as possible. In these experiments, measurements were normally made once every $2 \mathrm{~s}$.

Calibration of $\mathrm{Ca}^{2+}$ signals

Free $\left[\mathrm{Ca}^{2+}\right]$ was estimated from the ratio $(R)$ of fluorescence at 340 and $380 \mathrm{~nm}$, using the following equation: $\left[\mathrm{Ca}^{2+}\right]=K_{\mathrm{d}} \times$ slope factor $\times\left(R-R_{\min }\right) /\left(R_{\max }-R\right)$ (Grynkiewicz et al., 1985). The $K_{\mathrm{d}}$ was assumed to be $140 \mathrm{~nm}$, whereas values for $R_{\min }$ and $R_{\max }$ were all determined via calibration methods. An in vitro method (fura-2 $\mathrm{Ca}^{2+}$ imaging calibration kit; Invitrogen) was used to make estimate values. With this method, glass coverslips were filled with a high- $\mathrm{Ca}^{2+}$ (fura-2 plus $10 \mathrm{mM} \mathrm{Ca}^{2+}$ ), a low-Ca ${ }^{2+}$ (fura-2 plus 10 mM EGTA), and a control solution without fura-2. Each solution also contains a dilute suspension of $15 \mu \mathrm{m}$ polystyrene microspheres to ensure uniform coverslip/slide separation and facilitate microscope focusing. The fluorescence $(F)$ at $380 \mathrm{~nm}$ excitation of the low $\mathrm{Ca}^{2+}$ solution was imaged, and the exposure of the camera was adjusted to maximize the signal. These camera settings were then fixed, and measurements were made with 380 and $340 \mathrm{~nm}$ excitation of the three solutions: $R_{\min }=F_{340 \mathrm{~nm}}$ in low $\mathrm{Ca}^{2+} / F_{380 \mathrm{~nm}}$ in low $\mathrm{Ca}^{2+} ; R_{\max }=F_{340 \mathrm{~nm}}$ in high $\mathrm{Ca}^{2+} / F_{380 \mathrm{~nm}}$ in high $\mathrm{Ca}^{2+}$; and $S f=$ $F_{380 \mathrm{~nm}}$ in low $\mathrm{Ca}^{2+} / F_{380 \mathrm{~nm}}$ in high $\mathrm{Ca}^{2+}$.

Correlation analysis

Enriched oligodendrocytes were prepared as described by AmurUmarjee et al. (1993). Cells plated onto poly- ${ }_{\mathrm{d}}$-lysine-coated $12 \mathrm{~mm}$ glass coverslips were transfected using the Lipofectamine 2000 (Invitrogen). Briefly, $1 \mu \mathrm{g}$ of plasmid DNA (full-length golli-J37 clone in pEGFP-N3) (Reyes and Campagnoni, 2002) was used to transfect $4 \times 10^{4}$ cells per coverslip. While the DNA was complexing, the cells were washed for 5 min with serum free media. The complexed DNA mixture was then applied to the coverslips and incubated at $37^{\circ} \mathrm{C}, 5 \% \mathrm{CO}_{2}$ for $6 \mathrm{~h}$. The samples were washed with media supplemented with $10 \%$ FBS and subsequently incubated in defined culture media (Agresti et al., 1996) plus PDGF (10 ng/ml) and bFGF (10 ng/ml) for $2 \mathrm{~d}$ before use. Correlation studies of golli-GFP with $\mathrm{Ca}^{2+}$ influx kinetics were done by confocal microscopy using an Olympus spinning disc confocal equipment. Timelapse digital images were analyzed using the Pearson's correlation coefficient $(R r)$ facility, which is provided by Image analysis software (SlideBook 4.1; Intelligent Imaging Innovations). $R r$ is a well-defined and commonly accepted means for describing the extent of correlation between image pairs. It is a value ranging between -1.0 and 1.0 ; a -1.0 value signifies no correlation, whereas a value of 1.0 signifies perfect correlation (Manders et al., 1993).

\section{Statistical analysis}

Data are presented as mean \pm SEM unless otherwise noted. For fura-2 and cell cycle time experiments, statistical comparison between different experimental groups was performed by analysis of covariance. Measurements of the percentage of positive cells (phospho-Histone $\mathrm{H} 3$ and $\mathrm{BrdU}$ ) were performed using Student's paired $t$ test, in which $p<0.05$ was defined as statistically significant.

\section{Results}

Golli enhances store-operated $\mathrm{Ca}^{2+}$ uptake in OPCs

We have found that the golli proteins function as new and novel modulators of intracellular $\mathrm{Ca}^{2+}$ levels in OPCs, T-cells, and 
probably neurons (Feng et al., 2006; Paez et al., 2007, 2009a,b). To characterize further the $\mathrm{Ca}^{2+}$ channels regulated by golli, we examined the contribution of storeoperated $\mathrm{Ca}^{2+}$ entry in OPCs cultured from golli $\mathrm{KO}$ and JOE mice. Primary cultures of OPCs were first loaded with a membrane-permeable form of the $\mathrm{Ca}^{2+}$ indicator dye fura-2, before treatment with several agonists to activate different mechanisms that generate $\mathrm{Ca}^{2+}$ signaling in OPCs. Initially we sought to examine the effect of golli proteins on $\mathrm{Ca}^{2+}$ efflux from intracellular stores. $\mathrm{Ca}^{2+}$ responses to caffeine and thapsigargin ( $\mathrm{Tg}$ ) were studied in golli $\mathrm{KO}$ and JOE OPCs. Caffeine $(2 \mathrm{~mm})$ and thapsigargin $(100 \mathrm{~nm})$ both elicited a large and persistent increase in intracellular $\mathrm{Ca}^{2+}$ in the presence of normal extracellular $\mathrm{Ca}^{2+}(2 \mathrm{~mm})$ (Fig. $1 A$ ). This response was significantly higher in JOE OPCs and lower in golli KO cells. The effect of extracellular $\mathrm{Ca}^{2+}$ on caffeine and thapsigargin responses was examined in parallel cultures by perfusion with caffeine or thapsigargin in $\mathrm{Ca}^{2+}$-free medium. This evoked a slow-onset transient elevation of intracellular $\mathrm{Ca}^{2+}$ in all the OPC genotypes. This response was typically small in amplitude, and, under this experimental condition, we did not find any appreciable difference between golli $\mathrm{KO}$ and JOE OPCs compared with genotype control cells (Fig. $1 A$ ). Subtraction of responses in $\mathrm{Ca}^{2+}$-free medium from those in normal extracellular $\mathrm{Ca}^{2+}$ revealed a slow-onset extracellular $\mathrm{Ca}^{2+}$ -

dependent response to caffeine and thapsigargin, which began after most of the store depletion $\left(\mathrm{Ca}^{2+}\right.$ response in $\mathrm{Ca}^{2+}$-free medium) had occurred. The usual explanation for this phenomenon is activation of $\mathrm{Ca}^{2+}$ entry across SOCCs in the plasma membrane, subsequent to store depletion (Putney, 1993; Simpson et al., 1997). To examine the contribution of SOCC entry, fura-2-loaded OPCs were first pretreated with thapsigargin in the presence of zero $\mathrm{Ca}^{2+}$ to deplete intracellular stores and then reexposed to a $\mathrm{Ca}^{2+}$-containing medium to trigger $\mathrm{Ca}^{2+}$ influx via SOCCs. Reexposure to $\mathrm{Ca}^{2+}$-containing medium triggered a significantly larger increase in the fura- 2 signal in JOE cells compared with responses in genotype controls (Fig. $1 B$ ). Interestingly, opposite effects were observed in golli-deficient OPCs (Fig. $1 B)$. Additional pharmacological experiments in JOE cells treated with thapsigargin in zero $\mathrm{Ca}^{2+}$ medium demonstrated that the increased $\mathrm{Ca}^{2+}$ response was insensitive to $\mathrm{Cd}^{2+}$ and verapamil (Fig. 2D) and was abolished in the presence of the SOCCs inhibitors $\mathrm{La}^{2+}$ and 2-APB (Fig. $2 B, D$ ), confirming that this $\mathrm{Ca}^{2+}$ influx is not carried by voltage-operated $\mathrm{Ca}^{2+}$ channels (VOCCs), and more likely reflects influx via SOCCs. Similar results were found using MRS-1845, a specific blocker of storeoperated $\mathrm{Ca}^{2+}$ entry that does not activate intracellular $\mathrm{Ca}^{2+}$ release (Fig. 2C,D).

Together, these data indicate an important role for golli proteins in the regulation of SOCC-mediated $\mathrm{Ca}^{2+}$ influx. As a whole, these results suggest that $\mathrm{Ca}^{2+}$ release from ER stores might not be affected by golli but rather that golli regulates $\mathrm{Ca}^{2+}$ influx after store depletion, probably mediated by SOCCs.

\section{In situ imaging studies reveal store-activated $\mathrm{Ca}^{2+}$ currents in OPCs}

We performed in situ experiments using live tissue sections to examine $\mathrm{Ca}^{2+}$ influx in GFP-labeled OPCs in golli KO and JOE mice. These experiments were performed using doubletransgenic mice created by breeding the golli $\mathrm{KO}$ and JOE mice with a line expressing GFP under control of the PLP promoter (Mallon et al., 2002). In these mice, GFP expression provides a convenient marker for cells in the oligodendroglial lineage, thus facilitating experiments aimed at imaging OPCs in live tissue slices. Initially, we focused our in situ measurements of OPC in slice preparations containing the lateral ventricle subventricular zone (SVZ) because this region has been well studied as a source of OPCs. Our goal in these experiments was to confirm the in vitro data in live preparations with respect to SOCC activity in OPCs lacking golli or overexpressing golli. Recordings were made at $\mathrm{P} 4$. To examine in situ SOCC $\mathrm{Ca}^{2+}$ entry, fura-2-loaded tissue slices were first pretreated with thapsigargin $(\mathrm{Tg})$ in the presence of zero $\mathrm{Ca}^{2+}$ to deplete intracellular stores and then reexposed to a $\mathrm{Ca}^{2+}$-containing medium to trigger $\mathrm{Ca}^{2+}$ influx via SOCCs. Reexposure to $\mathrm{Ca}^{2+}$-containing medium triggered a significantly larger increase in the $\left[\mathrm{Ca}^{2+}\right]$ int in JOE SVZ cells compared with control OPCs (Fig. 3A-C). Furthermore, pharmacological ex- 
A

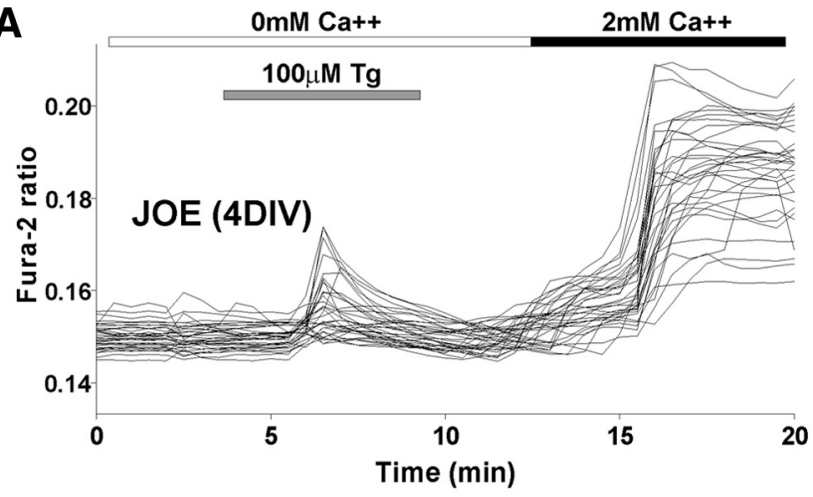

B
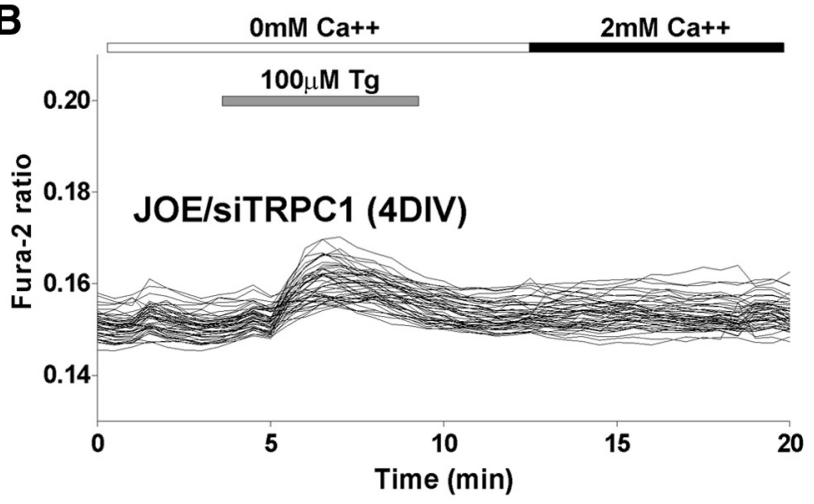

C

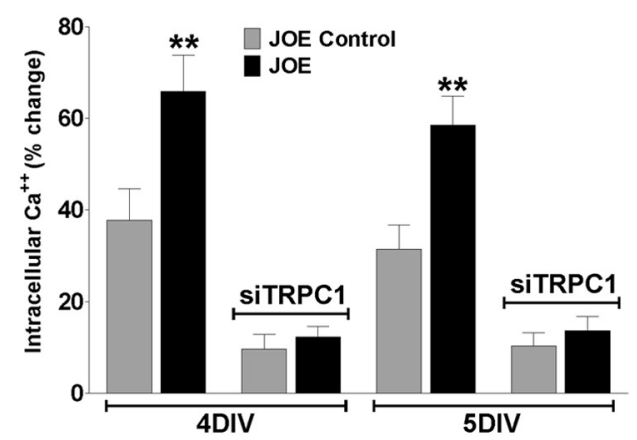

Figure 6. $\quad A, B, S O C C$ activity was examined in JOE OPCs pretreated with Tg in the presence of zero $\mathrm{Ca}^{2+}$ medium. After 1 DIV, JOE cells were transiently transfected with a combination of three different siRNA duplexes specific for TRPC1 (siTRPC1) and grown for 2 d in defined culture medium. $\mathrm{Ca}^{2+}$ entry experiments were performed after 3 and $4 \mathrm{~d}$ of siRNA transfection (i.e., 4 and 5 DIV). C, The graphs shows the average amplitude calculated from the responding cells expressed as percentage of change of the emission intensities for each experimental condition. Values are expressed as mean \pm SEM of at least four independent experiments ( $n>400$ cells for each condition). ${ }^{* *} p<0.01$ versus respective controls.

periments demonstrated that the increased $\mathrm{Ca}^{2+}$ response seen in JOE cells was abolished in the presence of 2-APB and MRS-1845, specific SOCCs blockers (Fig. 3D). As expected, golli $\mathrm{KO}$ cells exhibited $\mathrm{Ca}^{2+}$ signaling after stimulation with thapsigargin in the presence of zero $\mathrm{Ca}^{2+}$, but these $\mathrm{Ca}^{2+}$ signals were significantly weaker than that of the control cells (Fig. 3E). Additional experiments were made at P7, P14, and $\mathrm{P} 21$, allowing analysis of the developmental regulation of storeoperated $\mathrm{Ca}^{2+}$ influx in OPCs. In agreement with our previous findings, $\mathrm{Ca}^{2+}$ uptake after store depletion was significantly greater in golli-overexpressing cells located in the SVZ at all time points tested (Fig. $3 F$ ). However, no significant differences between JOE and control cells were found in the corpus callosum of 21-d-old mice (Fig. $3 F$ ), suggesting that golli modulation of SOCCs may play a role during the early stages of OPC matura- tion. Together, and in agreement with our previous data from cultured OPCs, these in situ results uncover a key role for golli protein in the regulation of SOCC-mediated $\mathrm{Ca}^{2+}$ influx in SVZ and CC OPCs.

\section{Blockage of TRPC1 reduces store-operated $\mathrm{Ca}^{2+}$ entry in OPCs}

Oligodendrocytes express TRPC channels that have been implicated in mediating store-operated $\mathrm{Ca}^{2+}$ entry (Fusco et al., 2004; Weerth et al., 2007). Using an antibody against TRPC1, we were able to block the function of TRPC1 channels and demonstrate their involvement in golli-evoked $\mathrm{Ca}^{2+}$ entry in cultured OPCs. We used an antibody against TRPC1 that was designed to bind to amino acid residues 557-571 in the proposed pore-forming region of human/mouse TRPC1 and block the functioning of the channel (Wang et al., 1999). This antibody has been used to block TRPC1 current (Kim et al., 2003) and TRPC1-mediated $\mathrm{Ca}^{2+}$ influx (Xu and Beech, 2001; Antoniotti et al., 2002). Therefore, this antibody can specifically block the function of TRPC1containing channels and determine the extent of their involvement in SOC entry. Cultured OPCs were pretreated with thapsigargin in the presence of zero $\mathrm{Ca}^{2+}$ to deplete intracellular stores, but in this case cells were preincubated with TRPC1 antibody $(10 \mu \mathrm{g} / \mathrm{ml}$ for $1 \mathrm{~h})$ before $\mathrm{Ca}^{2+}$ readdition to allow the antibody sufficient time to bind and block the channels. Preincubation with the antibody caused a significant decrease in the measured amount of store-operated $\mathrm{Ca}^{2+}$ entry compared with JOE cells that were not incubated with TRPC1 antibody (Fig. 4A,B). This decrease in $\mathrm{Ca}^{2+}$ entry was of a similar proportion to that seen using SOCC blockers (2-APB and MRS-1845), indicating that TRPC1 is involved in mediating store-operated $\mathrm{Ca}^{2+}$ uptake in golli-overexpressing OPCs. It also represents the first time this channel has been shown to be functional in OPCs. Furthermore, the effect of anti-TRPC1 was abolished by preincubation of the antibody with the antigen peptide (+Pept), underlying the specificity of the primary antibody (Fig. 4C,D).

To determine which TRPC homologs are expressed in OPCs, semiquantitative RT-PCR reactions were run using primers specific for individual TRPC homologs (Table 1). As shown in Figure 5A, OPCs express mRNA for TRPC1, TRPC2, TRPC3, TRPC4, TRPC5, and TRPC6. Importantly, no significant differences in TRPC expression were observed between control and gollioverexpressing OPCs (Fig. 5A). To confirm the role of TRPC1 in mediating SOC uptake in golli-overexpressing OPCs, we used an siRNA approach to selectively suppress mRNA levels for TRPC1. Twenty four hours after plating, OPCs were transiently transfected with a combination of three different siRNA duplexes specific for TRPC1 (Table 2). Two days later, the mRNA levels were monitored using semiquantitative RT-PCR methods. The data in Figure $5 B$ illustrate the selective suppression of TRPC 1 mRNA by expression of siRNA specific for that TRPC homolog. Thus, levels of TRPC1 mRNA could be selectively suppressed by $\sim 90 \%$. Western blots were performed to confirm that TRPC1 protein levels were also suppressed by siRNA expression. The Western blots in Figure $5 C$ illustrate that the specific reduction in mRNA for TRPC1 is accompanied by a reduction of $\sim 95 \%$ in TRPC1 protein levels (Fig. 5 C). The effect of suppression of TRPC1 homolog on the level of SOC influx was then determined by monitoring thapsigargin stimulation of $\mathrm{Ca}^{2+}$ entry in JOE cells at 4 and 5 DIV. The suppression of TRPC1 protein levels produced an $\sim 80 \%$ inhibition of thapsigargin-stimulated $\mathrm{Ca}^{2+}$ influx at both 4 and 5 DIV (Fig. 6), indicating that TRPC1 is heavily involved in mediating SOC entry in golli-overexpressing OPCs. 
Inhibition of TRPC1 significantly attenuates proliferation in JOE cells Proliferation of OPCs is clearly important for normal myelination as well as for remyelination in demyelinating diseases. Our recently published data (Paez et al., 2009a) indicate that golli enhances the proliferative activity of PDGF, a potent mitogen for OPCs (Noble et al., 1988; Raff et al., 1988; Calver et al., 1998).

To investigate the physiological relevance of TRPC1 expression in OPCs, we used an siRNA approach to knock down the expression of TRPC1 channel and measure proliferation and cell cycle time to determine whether TRPC channels are involved in golli-induced OPC proliferation. Twenty four hours after plating, OPCs were transiently transfected with a combination of three different siRNA duplexes specific for TRPC1 (Table 2). Two days later, the medium was changed and the cells were grown in the presence of PDGF (20 ng/ml) for $48 \mathrm{~h}$. Because actively proliferating cells duplicate their DNA content, we labeled proliferating OPCs from control and JOE mice with the thymidine analog BrdU. Twenty four hour pulses of $10 \mu \mathrm{m}$ BrdU were performed at 3 and 4 DIV (Fig. 7A). After each BrdU pulse, proliferating progenitors were identified by double immunofluorescence for BrdU and NG2, and the relative number of $\mathrm{NG}^{+} / \mathrm{BrdU}^{+}$cells was quantified in each cell population (Fig. $7 B$ ). In agreement with our previous findings ( $\mathrm{Paez}$ et al., 2009a), at 4 and 5 DIV, the average number of proliferating cells in the JOE population was significantly higher than that of the control group (Fig. 7C). However, after TRPC1 knockdown, the average percentage of proliferating OPCs in the golli-overexpressing cell population was found to be significant lower compared with nontransfected JOE cells, and additionally no significant differences between JOE and control cells were found (Fig. 7C).

The BrdU cell proliferation results in the JOE OPC population were confirmed using an anti-phospho-Histone-H3 (Ser28) antibody as a marker of mitotic cells. Phosphorylation of Histone $\mathrm{H} 3$ at Ser10 and Ser28 is very important for chromosome condensation and segregation during mitosis (Wei et al., 1999). The phosphorylation of Histone $\mathrm{H} 3$ at Ser28 occurs in chromosomes predominantly during early mitosis and coincides with the initiation of mitotic chromosome condensation in various mammalian cell lines (Goto et al., 1999). At 4 and 5 DIV, in the presence of $20 \mathrm{ng} / \mathrm{ml}$ PDGF, there were more $\mathrm{H}_{3}{ }^{+}$cells in the golli-overexpressing cell population than in the control cells (Fig. 7D), but 24 and $48 \mathrm{~h}$ after TRPC1 knockdown ( 4 and 5 DIV) no significant differences between groups were found (Fig. 7D).

Additionally, we measured the Tc and the percentage of mitotic OPCs of the JOE and control cells by performing time-lapse imaging in mixed glial cultures using GFP-labeled OPCs as we have done
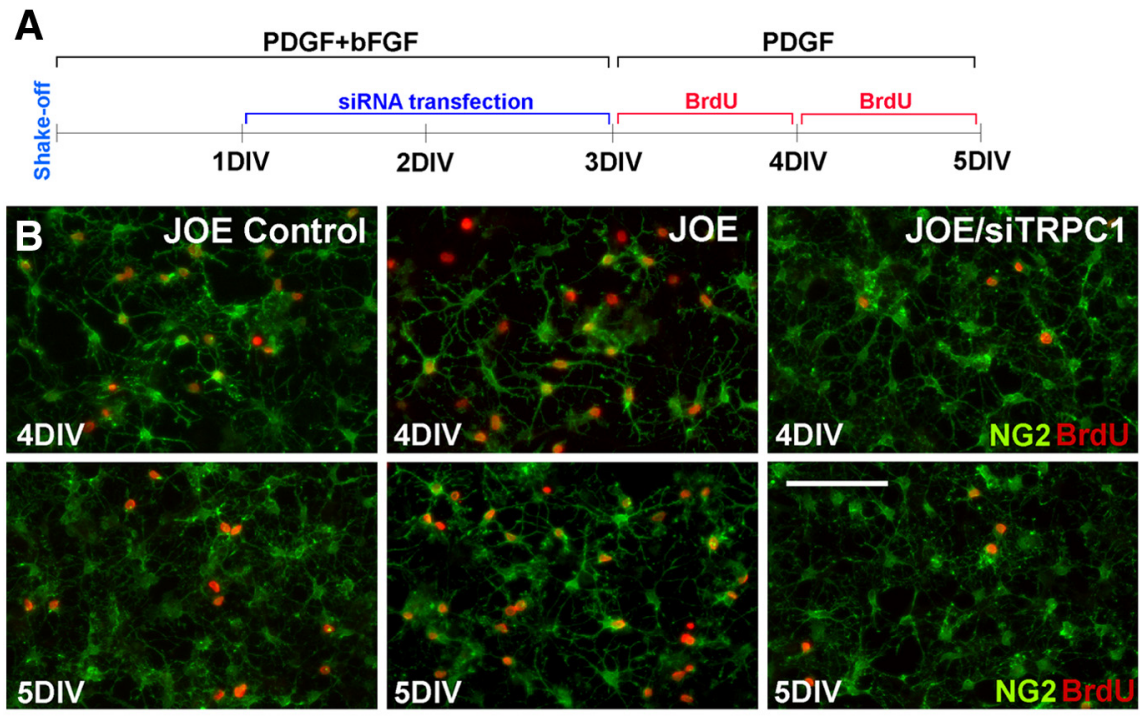

C $_{60}$

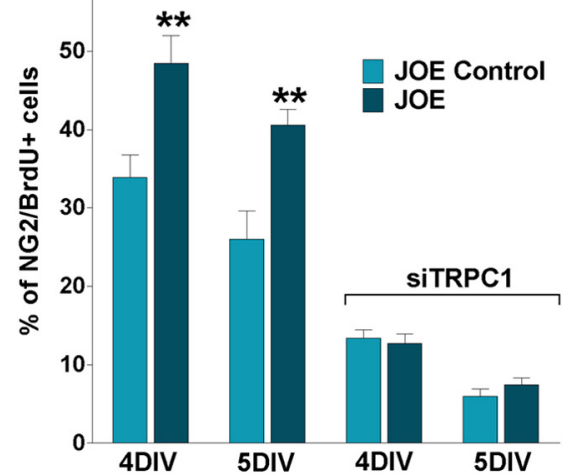

$D_{20}$

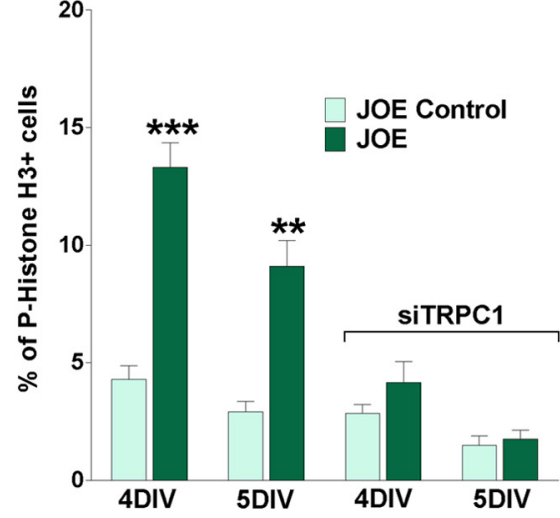

Figure 7. A, Twenty four hours after plating, pure OPC cultures from JOE mice were transiently transfected with a combination

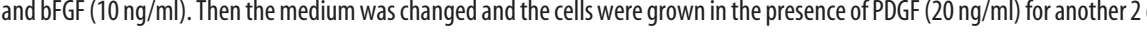
and 5 DIV). Twenty-four-hour pulses of $10 \mu \mathrm{m}$ BrdU were begun at 3 and 4 DIV. After each BrdU pulse, cells were fixed and

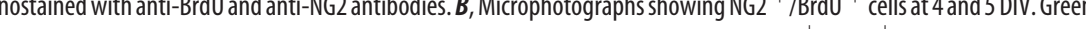
was compared with respective controls. $\boldsymbol{D}$. The percentage of phospho-Histone $\mathrm{H}^{+}{ }^{+}$cells in each experimental condition was measured as described in Materials and Methods. Values are expressed as mean \pm SEM of four independent experiments. ${ }^{* *} p<$ $0.01,{ }^{* * *} p<0.001$ versus respective controls.

previously (Paez et al., 2009a). We imaged individual clones of GFPlabeled OPCs (OPC-GFP) in the presence of an astrocyte monolayer, a known source of growth factors such as PDGF and bFGF (Hinks and Franklin, 1999). These experiments were performed for a period of $48 \mathrm{~h}$ at 4 and 6 DIV before the shake off (Fig. $8 \mathrm{~A}$ ). In these time-lapse experiments, the role of TRPC1 on cell proliferation was assessed by calculating the average Tc in different OPC-GFP clones using an anti-TRPC antibody to block the functioning of TRPC1 channels. Cell cycle time was defined as the period between the cytokinesis at which a cell was generated and when the cell divided, giving birth to two daughter cells. The time at which cytokinesis occurred was considered to be the first appearance of a distinct border between two daughter cells in a video microscopic image sequence (see Materials and Methods). Examples of cytokinetic events in GFP-labeled OPCs from JOE mice grown for $4 \mathrm{~d}$ on an astrocyte monolayer are shown in Figure $8 \mathrm{~B}$. At 4 DIV, control OPCs showed a Tc of $\sim 24 \mathrm{~h}$, whereas the JOE cells showed a Tc of $\sim 18 \mathrm{~h}$. In contrast, the proliferation rate of JOE OPCs was increased to a Tc $\sim 31$ h at 4 DIV and $\sim 34$ h at 6 DIV 
A

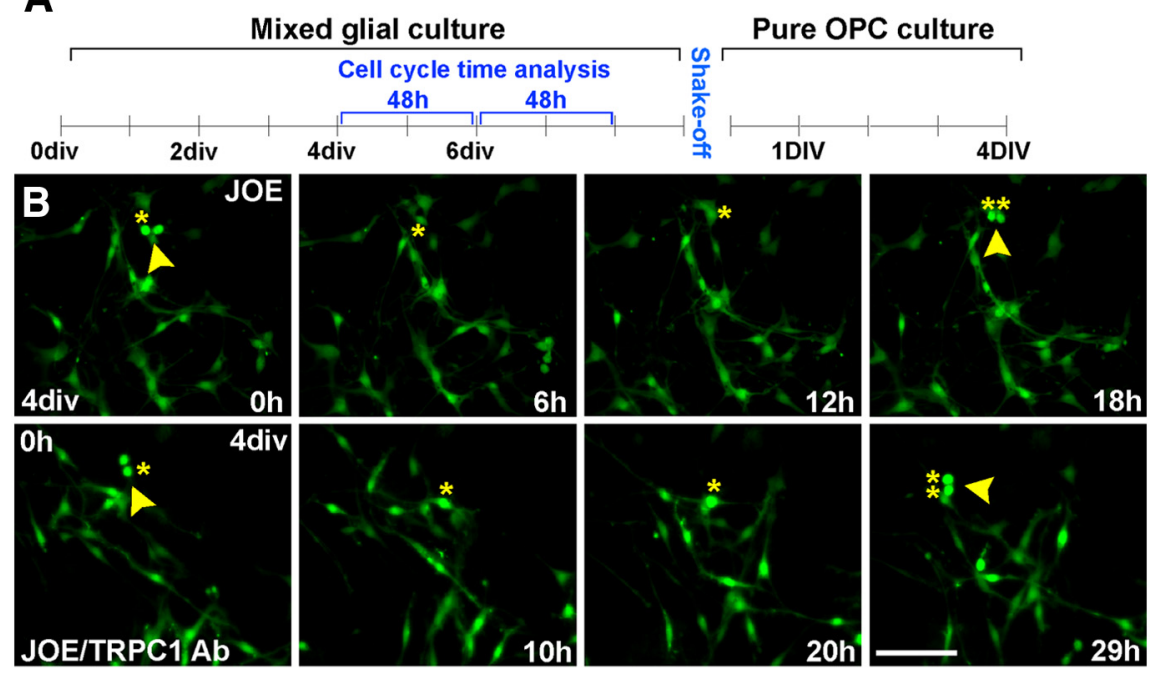

C 40

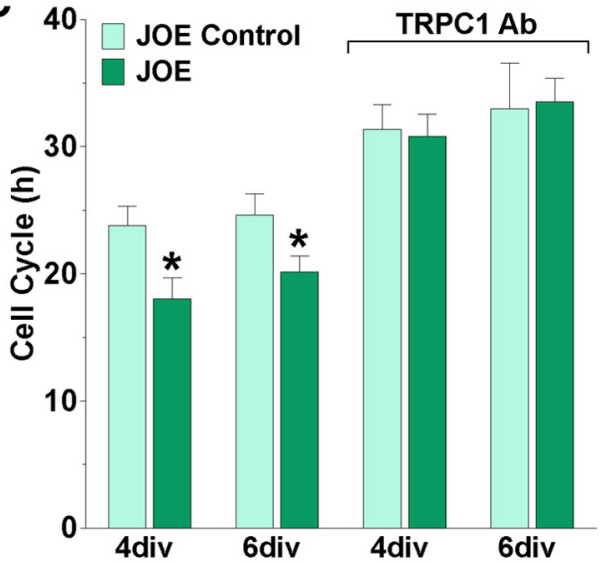

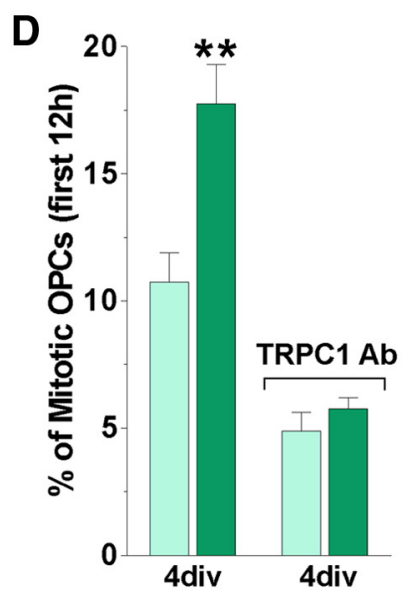

Figure 8. A, Mixed glial cultures were incubated in a chamber with $5 \% \mathrm{CO}_{2}$ at $37^{\circ} \mathrm{C}$, which was placed on the stage of a spinning disc confocal inverted microscope. GFP-labeled OPC clones were imaged with a specific GFP filter at 6 min intervals for a period of $48 \mathrm{~h}$ beginning at 4 and 6 DIV before the shake off. $\boldsymbol{B}$, Time-lapse series of OPC-GFP clones from JOE mice grown for $4 \mathrm{~d}$ on an astrocyte monolayer (4DIV) and incubated with an antibody against TRPC1 (TRPC1 Ab) (10 $\mu \mathrm{g} / \mathrm{ml})$. Yellow arrowheads designate cytokinesis events. Tracking of cells between birth cytokinesis and division cytokinesis was noted with a yellow asterisk near the cell, which was generated from frame to frame. Each frame represents a single section of a time-lapse video sequence. Time is denoted in hours in the bottom right corner. Scale bar, $60 \mu \mathrm{m}$. C, D, Estimated Tcs and percentage of mitotic OPCs were determined as described in Materials and Methods for each experimental condition. Values are expressed as mean $\pm \mathrm{SEM}$ of four independent experiments. ${ }^{*} p<0.05,{ }^{* *} p<0.01$ versus control.

in the presence of TRPC1 antibody used to block TRPC1mediated $\mathrm{Ca}^{2+}$ influx (Fig. 8C). Furthermore, as shown in Figure $8 \mathrm{D}$, the percentage of cycling OPCs during the first $12 \mathrm{~h}$ of the time-lapse experiment was significantly higher in the JOE cell population, suggesting that the fraction of proliferating OPCs is increased by golli overexpression.

These results indicated, by several independent measures, that golli promoted OPC proliferation in the presence of growth factors, i.e., an increase in the number of $\mathrm{BrdU}^{+}$cells, a decrease in the cell cycle time, and an increase in the number of cells in S phase. This effect disappeared when TRPC1 expression was suppressed by specific siRNAs or when the channel was blocked by specific antibodies, indicating that golli influences OPC proliferation by modulating $\mathrm{Ca}^{2+}$ influx through TRPC1. Additionally, these experiments are the first to demonstrate that extracellular $\mathrm{Ca}^{2+}$ uptake through TRPC1 is an important component in the mechanism of OPC proliferation.
Golli colocalizes with TRPC1 $\mathrm{Ca}^{2+}$ channels in OPC processes

Using digital confocal analysis, we found TRPC1 expression throughout the cell body and processes of OPCs (Fig. 9A). A number of circular "hotspots" were found in the cell body and along OPC processes. TRPC1 expression was highly varied such that certain sites along the processes were found to possess markedly higher levels of TRPC1 than surrounding regions (Fig. 9A). We then examined whether these patches of TRPC1 expression along OPC processes were associated with golli. Double immunofluorescence for golli and TRPC1 revealed that cell regions with TRPC1 accumulations tended to colocalize with high levels of golli expression along OPC processes (Fig. 9B). To examine whether the sites of high-density golli protein distribution were related to the sites of high SOC influx kinetics, we performed correlation experiments between golli-GFP expression and $\mathrm{Ca}^{2+}$ levels in OPC processes. We stimulated OPCs overexpressing golliGFP with thapsigargin in the presence of zero $\mathrm{Ca}^{2+}$ to deplete intracellular stores and then reexposed to a $\mathrm{Ca}^{2+}$-containing medium to trigger $\mathrm{Ca}^{2+}$ influx via SOCCs. The kinetics of the resulting $\mathrm{Ca}^{2+}$ influx was measured in serial $z$-sections along cell processes. The pattern of golliGFP fluorescence was then imaged, and the intensities were measured within the same serial sections of the cell in which the $\mathrm{Ca}^{2+}$ influx kinetics were measured. The resultant profile was then compared with the profile of $\mathrm{Ca}^{2+}$ influx kinetics using correlation analysis (see Materials and Methods). In the OPC processes, the Pearson's $R r=0.912 \pm 0.034(n=25)$, indicating that there is a significant overlap of golli-GFP and SOC influx sites in OPCs processes. A plot of the local $\mathrm{Ca}^{2+}$ amplitudes against the length of the process, together with the intensity of golliGFP measured in the same cellular sites, showed that the regions with high-intensity golli-GFP corresponded closely with the regions of the process in which the local peak $\mathrm{Ca}^{2+}$ amplitudes were highest (Fig. 9C,D). These studies indicated that golli is probably associated with TRPC1 at discrete cellular regions. Such high-density golli and TRPC1 expression at these sites would be expected to participate in the regulation of $\mathrm{Ca}^{2+}$ uptake in these cellular microdomains.

\section{Discussion}

Golli proteins promote $\mathrm{Ca}^{2+}$ influx after $\mathrm{Ca}^{2+}$-store mobilization

In many cells, including OLs, an important mechanism for stimulating $\mathrm{Ca}^{2+}$ influx is through SOCCs, located in the plasma membrane (Simpson and Russell, 1997). The SOCCs are stimulated to take up $\mathrm{Ca}^{2+}$ from increases in internal $\mathrm{Ca}^{2+}$ concentrations through depletion of the internal stores, primarily from the ER. Release occurs via inositol 1,4,5-triphosphate $\left(\mathrm{IP}_{3}\right)$ or ryanodine 
receptors, and $\mathrm{Ca}^{2+}$ is subsequently resequestered into stores via sarcoplasmicendoplasmic reticulum $\mathrm{Ca}^{2+}$ ATPases (SERCAs) (Berridge, 1993; Simpson et al., 1995). In many cell types, SERCA inhibition leads to elevation of cytosolic $\mathrm{Ca}^{2+}$ secondary to leakage of $\mathrm{Ca}^{2+}$ from stores. Thapsigargin is used to inhibit SERCA pumps in cultured cells, and it has been demonstrated that SERCA-mediated store depletion activates store-operated $\mathrm{Ca}^{2+}$ entry in glial cells (Simpson and Russell, 1997). The results presented here show that inhibition of SERCA pumps by thapsigargin or ryanodine receptor activation by caffeine evokes significant $\mathrm{Ca}^{2+}$ release from intracellular stores and $\mathrm{Ca}^{2+}$ entry after store depletion in OPCs. Our data clearly indicated that, under these pharmacological treatments, golli promoted a significant activation of SOCCs and $\mathrm{Ca}^{2+}$ uptake both in vitro (cultured OPCs) and in situ (slice preparation). Importantly, this increased $\mathrm{Ca}^{2+}$ influx in JOE cells was totally abolished by the specific SOCC inhibitors 2-APB and MRS-1845, confirming that this influx is carried by SOCCs.

\section{TRPC1 mediates golli effect on store-} operated $\mathrm{Ca}^{2+}$ entry

In addition to entry through voltagegated calcium channels and release from intracellular stores, members of the TRP channel superfamily present an alternative mechanism for $\mathrm{Ca}^{2+}$ entry and regu-

late multiple processes in the developing and mature nervous system. TRP channels are a family of 28 nonselective cation channels, and all except TRPM4 and TRPM5 display varying degrees of calcium permeability (Nilius et al., 2007). Members of the TRPC family are involved in SOC entry (Zitt et al., 2002; Smyth et al., 2006; Liao et al., 2007), which is thought to be an essential component in establishing intracellular $\mathrm{Ca}^{2+}$ concentrations (Woods et al., 1986; Foskett and Wong, 1994). The expression of TRPC1 and TRPC3 proteins have been reported in OLs (Fusco et al., 2004; Weerth et al., 2007), and we have found by RT-PCR that TRPC1-TRPC6 are expressed in cultured OPCs.

In the mature nervous system, TRP channels play important roles in the processing of sensory information (Clapham, 2003) and fear-related learning and memory (Riccio et al., 2009), and defects in particular channels underlie models of neurodegeneration such as cerebellar ataxia (Becker et al., 2009). During early development, members of the TRP channel families modulate neural progenitor proliferation (Fiorio Pla et al., 2005), whereas at later stages specific members of the TRPC family have been shown to both positively and negatively regulate neurite extension (Greka et al., 2003; Wu et al., 2008), likely because of the activation of $\mathrm{Ca}^{2+}$-dependent processes (Gomez and Zheng, 2006).

In this study, we demonstrated that a large portion of SOC entry in cultured OPCs is likely mediated through TRPC1containing channels in the plasma membrane. We demonstrated that $\mathrm{Ca}^{2+}$ entry via TRPC1 plays an important role in oligodendrocyte $\mathrm{Ca}^{2+}$ dynamics. We found that, after thapsigargin treatment, in the presence of zero $\mathrm{Ca}^{2+}$ reexposure to a $\mathrm{Ca}^{2+}$ -
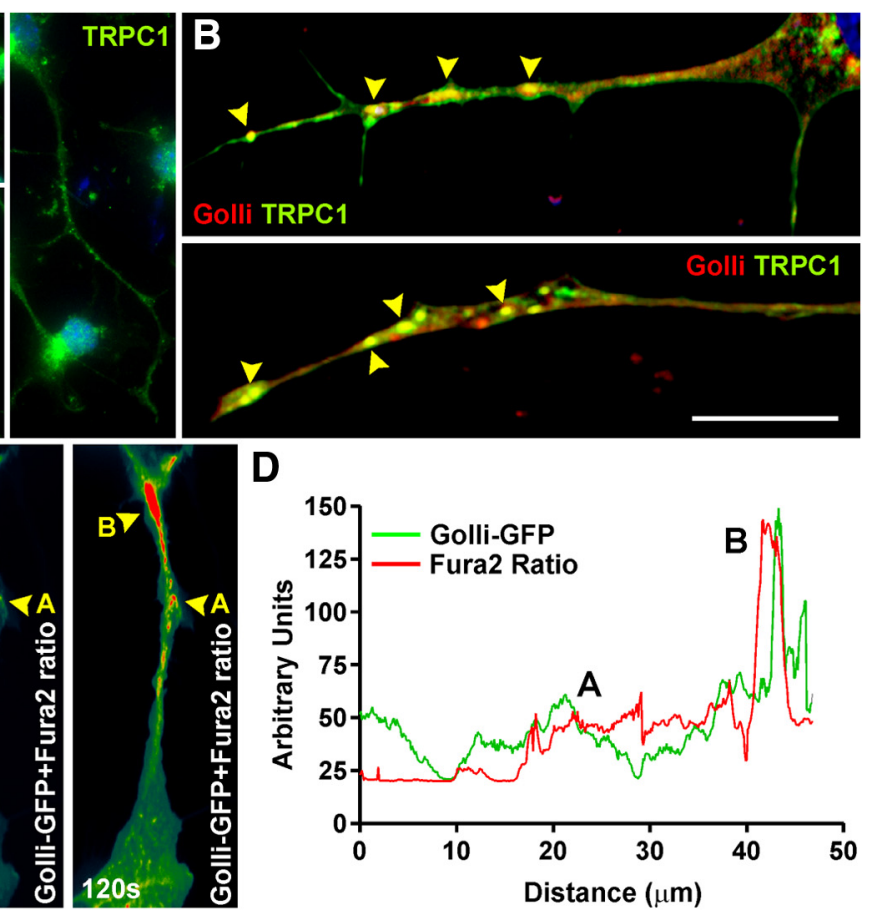

\section{0}

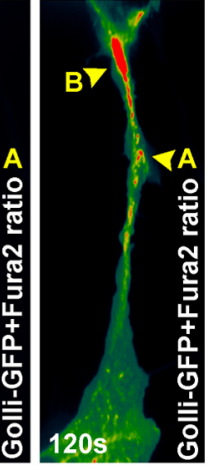

Distance $(\mu \mathrm{m})$

Figure 9. $A$, Confocal microscopy analysis of JOE OPCs reveal high TRPC1 expression in certain sites along the processes and soma of the cells. Scale bar, $25 \mu \mathrm{m}$. B, J0E OPCs were immunostained for golli (red) and TRPC1 (green). Merged images show areas amplitudes after reexposure to $\mathrm{Ca}^{2+}$-containing medium (120 s) (red line) along the process are shown compared with golli-GFP fluorescence measurement (green line) in the same cellular sections.

containing medium caused an increase in cytoplasmic $\mathrm{Ca}^{2+}$, which was reduced by $\sim 80 \%$ when TRPC1 was blocked by specific antibodies or siRNA expression. This may indicate that $\mathrm{Ca}^{2+}$ channels containing TRPC1 are dynamically refilling the intracellular stores during transient cytoplasmic $\mathrm{Ca}^{2+}$ increases in OPCs. Conversely, when TRPC1 was blocked in cells overexpressing golli, a significant reduction in $\mathrm{Ca}^{2+}$ uptake occurred after store depletion, suggesting an involvement of TRPC1 channels in the SOC influx induced by golli proteins. Together, the data presented here provide the first evidence for an involvement of a channel belonging to the TRPC family in store-operated $\mathrm{Ca}^{2+}$ influx in oligodendroglial cells.

A previous study has shown that TRPC1 can heterotetramerize with other TRPCs expressed during brain development to form complexes containing TRPC1/TRPC3/TRPC6 and TRPC1/ TRPC4/TRPC5, which give rise to channels with different properties (Strubing et al., 2003). We used RT-PCR to detect the presence of TRPC channels other than TRPC1 in primary culture of OPCs and found the presence of mRNAs for TRPC1, TRPC2, TRPC3, TRPC4, TRPC5, and TRPC6. Interestingly, no significant differences in the TRPC profiles were observed between control and golli-overexpressing OPCs. We found an 80\% reduction in OPC SOC uptake when TRPC1 was knocked down, indicating that TRPC1 is the most important SOCC isoform in OPCs, but our results do not exclude a possible involvement of other TRPC homologs during store-operated $\mathrm{Ca}^{2+}$ uptake in OPCs. Future studies will address whether other TRPC homologs are involved in OPC $\mathrm{Ca}^{2+}$ dynamics. 


\section{Store-operated $\mathrm{Ca}^{2+}$ uptake correlates with sites of high golli concentrations in OPC processes}

Simpson et al. (1997) have been able to localize microdomains of $\mathrm{Ca}^{2+}$ activity within OL processes. They have identified microdomains within OPC processes, indicating the infiltration of the ER into the OPC processes. In many instances, the ER lies in very close proximity to the plasma membrane of the processes in which $\mathrm{Ca}^{2+}$ channels are located. Thus, components of the $\mathrm{Ca}^{2+}$ release mechanism from internal stores can be in close proximity to SOCCs located on the plasma membrane surface. Such a structural arrangement can facilitate the $\mathrm{Ca}^{2+}$ waves along processes as well as initiate local $\mathrm{Ca}^{2+}$ responses in the processes. Recently, Weerth et al. (2007) have been able to identify signaling microdomains associated with lipid raft-like membrane specializations in glial cells. They also identified putative SOCC components and $\mathrm{IP}_{3} \mathrm{R} 2$ receptors, suggesting close interaction between $\mathrm{Ca}^{2+}$ signaling sites on the ER with those on the plasma membrane. Thus, $\mathrm{Ca}^{2+}$ signaling components are located within OPC processes, and they may play an important role in process elongation, retraction, and migration.

Using high-resolution spatiotemporal analysis, we showed that SOC influx in OPCs overexpressing golli initiated with different latencies at discrete cellular locations. Specifically, regions of the OL process with elevated golli levels consistently displayed higher-amplitude $\mathrm{Ca}^{2+}$ signals than were found in surrounding areas. We hypothesize that golli proteins are needed at waveamplification sites along OPC processes to regulate the activity of SOCCs located in close apposition to ER. The principal role of high golli levels may be to maintain locally high levels of $\mathrm{Ca}^{2+}$ within the ER and thereby contribute to elevated $\mathrm{Ca}^{2+}$ influx at wave-amplification sites.

A recent independent study has shown binding of golli proteins to STIM1, the master regulator of SOCCs (Walsh et al., 2010). Walsh and colleagues propose that golli functions to regulate SOC influx via a direct interaction with STIM1, but the exact molecular mechanism underlying this interaction has yet to be defined.

\section{Golli modulation of TRPC1 affects OPC proliferation}

Proliferation of OPCs is clearly important for normal myelination as well as for remyelination in demyelinating diseases. This study indicates that golli overexpression increases the proliferation rate of OPCs as assessed by several parameters, including a decrease in the cell cycle time. Our results indicated that endogenous golli expression can modulate OPC proliferation through SOCCs. More importantly, this effect disappeared when TRPC1 expression was suppressed by specific siRNAs or blocked by antibodies, indicating a key role for TRPC1 in OPC proliferation.

Jacobs et al. (2009) have shown previously that golli overexpression causes a significant delay in OPC maturation, with accumulation of significantly greater numbers of premyelinating OLs that fail to myelinate axons during the normal myelinating period. Although an increase in proliferating OPCs was not detected in this study, a greater number of OPCs were found in the JOE brain around the second postnatal week, suggesting that increased proliferation in the JOE mice may occur at early developmental stages.

Our recently published data indicate that golli enhances the proliferative activity of PDGF and that PDGF induced a biphasic transient increase in OPC intracellular $\mathrm{Ca}^{2+}$ (Paez et al., 2009a). The first phase occurred in the absence of external $\mathrm{Ca}^{2+}$ and was completely abolished by thapsigargin pretreatment, indicating that the first phase was attributable to $\mathrm{Ca}^{2+}$ release from intra- cellular stores. The second phase was completely abolished by store-operated $\mathrm{Ca}^{2+}$ channel inhibitors, indicating that these channels were involved in maintaining the elevated intracellular $\mathrm{Ca}^{2+}$ concentration characteristic of this phase. The storeoperated $\mathrm{Ca}^{2+}$ influx was higher in JOE cells, suggesting that the mechanism responsible for the effect of golli on OPC proliferation was mediated through an increase in store-operated $\mathrm{Ca}^{2+}$ influx. In this paper, we identified the channel responsible for this $\mathrm{Ca}^{2+}$ uptake increase in golli-overexpressing cells, and we revealed for the first time that extracellular $\mathrm{Ca}^{2+}$ uptake through TRPC1 is an important component in the mechanism of OPC proliferation. Recently, Cuddon et al. (2008) reported that PDGF activates store-operated $\mathrm{Ca}^{2+}$ entry in neuronal precursor cells, a finding that supports our data indicating that SOCCs are essential for neural cell division. Furthermore, several studies have shown that TRPC1 plays a role in $\mathrm{Ca}^{2+}$ influx and smooth muscle cell proliferation (Golovina et al., 2001; Sweeney et al., 2002a,b) and mediates $\mathrm{Ca}^{2+}$ influx activated by bFGF (FGF-2) in endothelial cells (Antoniotti et al., 2002).

We have found that golli regulates different aspects of OPC function through distinct routes of $\mathrm{Ca}^{2+}$ entry. Golli regulation of SOCCs influences OPC proliferation, and its modulation of VOCCs influences OPC process extension/migration (Paez et al., 2007, 2009b). How can these different routes of $\mathrm{Ca}^{2+}$ influx modulates different aspects of OPC development? The answer must lie in the pattern of $\mathrm{Ca}^{2+}$ signals in time and space evoked by the activation of different $\mathrm{Ca}^{2+}$ channels. $\mathrm{Ca}^{2+}$-sensitive sites that evoke process outgrowth and migration are located close to VOCCs (Bolsover, 2005), but TRPC1 activation, as occurs during store depletion in OPCs, will cause a significant increase of $\mathrm{Ca}^{2+}$ concentration within the ER activating cell proliferation.

In summary, the findings described in this work suggest a key role for golli proteins in the regulation of $\mathrm{OPC} \mathrm{Ca}^{2+}$ homeostasis. This involvement in $\mathrm{Ca}^{2+}$ signaling in the myelin forming cells of the CNS indicates that golli proteins can have a significant effect on the ability of OPCs to respond to remyelination cues in clinical situations resulting in demyelination. As such, golli proteins represent important molecules that may be of direct relevance to demyelinating diseases.

\section{References}

Agresti C, D’Urso D, Levi G (1996) Reversible inhibitory effects of interferon- $\gamma$ and tumour necrosis factor- $\alpha$ on oligodendroglial lineage cell proliferation and differentiation in vitro. Eur J Neurosci 8:1106-1116.

Alberdi E, Sánchez-Gómez MV, Matute C (2005) Calcium and glial cell death. Cell Calcium 38:417-425.

Amur-Umarjee S, Phan T, Campagnoni AT (1993) Myelin basic protein mRNA translocation in oligodendrocytes is inhibited by astrocytes in vitro. J Neurosci Res 36:99-110.

Antoniotti S, Lovisolo D, Fiorio Pla A, Munaron L (2002) Expression and functional role of bTRPC1 channels in native endothelial cells. FEBS Lett 510:189-195.

Becker EB, Oliver PL, Glitsch MD, Banks GT, Achilli F, Hardy A, Nolan PM, Fisher EM, Davies KE (2009) A point mutation in TRPC3 causes abnormal Purkinje cell development and cerebellar ataxia in moonwalker mice. Proc Natl Acad Sci U S A 106:6706-6711.

Belachew S, Malgrange B, Rigo JM, Rogister B, Leprince P, Hans G, Nguyen L, Moonen G (2000) Glycine triggers an intracellular calcium influx in oligodendrocyte progenitor cells which is mediated by the activation of both the ionotropic glycine receptor and $\mathrm{Na}^{+}$-dependent transporters. Eur J Neurosci 12:1924-1930.

Berridge MJ (1993) Inositol trisphosphate and calcium signalling. Nature 361:315-325.

Bolsover SR (2005) Calcium signalling in growth cone migration. Cell Calcium 37:395-402. 
Butt AM (2006) Neurotransmitter-mediated calcium signalling in oligodendrocyte physiology and pathology. Glia 54:666-675.

Calver AR, Hall AC, Yu WP, Walsh FS, Heath JK, Betsholtz C, Richardson WD (1998) Oligodendrocyte population dynamics and the role of PDGF in vivo. Neuron 20:869-882.

Campagnoni AT, Pribyl TM, Campagnoni CW, Kampf K, Amur-Umarjee S, Landry CF, Handley VW, Newman SL, Garbay B, Kitamura K (1993) Structure and developmental regulation of Golli-mbp, a 105-kilobase gene that encompasses the myelin basic protein gene and is expressed in cells in the oligodendrocyte lineage in the brain. J Biol Chem 268:4930-4938.

Clapham DE (2003) TRP channels as cellular sensors. Nature 426:517-524.

Colwell CS (2000) Circadian modulation of calcium levels in cells in the suprachiasmatic nucleus. Eur J Neurosci 12:571-576.

Cuddon P, Bootman MD, Richards GR, Smith AJ, Simpson PB, Roderick HL (2008) Methacholine and PDGF activate store-operated calcium entry in neuronal precursor cells via distinct calcium entry channels. Biol Res 41:183-195.

Feng JM, Hu YK, Xie LH, Colwell CS, Shao XM, Sun XP, Chen B, Tang H, Campagnoni AT (2006) Golli protein negatively regulates store depletion-induced calcium influx in T cells. Immunity 24:717-727.

Filipovic R, Rakic S, Zecevic N (2002) Expression of Golli proteins in adult human brain and multiple sclerosis lesions. J Neuroimmunol 127:1-12.

Fiorio Pla A, Maric D, Brazer SC, Giacobini P, Liu X, Chang YH, Ambudkar IS, Barker JL (2005) Canonical transient receptor potential 1 plays a role in basic fibroblast growth factor (bFGF)/FGF receptor-1-induced $\mathrm{Ca}^{2+}$ entry and embryonic rat neural stem cell proliferation. J Neurosci 25:2687-2701.

Foskett JK, Wong DC (1994) $\left[\mathrm{Ca}^{2+}\right]_{\mathrm{i}}$ inhibition of $\mathrm{Ca}^{2+}$ release-activated $\mathrm{Ca}^{2+}$ influx underlies agonist- and thapsigargin-induced $\left[\mathrm{Ca}^{2+}\right]_{\mathrm{i}}$ oscillations in salivary acinar cells. J Biol Chem 269:31525-31532.

Fulton D, Paez PM, Fisher R, Handley V, Colwell CS, Campagnoni AT (2010) Regulation of L-type $\mathrm{Ca}^{2+}$ currents and process morphology in white matter oligodendrocyte precursor cells by golli-myelin proteins. Glia 58:1292-1303.

Fusco FR, Martorana A, Giampà C, De March Z, Vacca F, Tozzi A, Longone P, Piccirilli S, Paolucci S, Sancesario G, Mercuri NB, Bernardi G (2004) Cellular localization of TRPC3 channel in rat brain: preferential distribution to oligodendrocytes. Neurosci Lett 365:137-142.

Golovina VA, Platoshyn O, Bailey CL, Wang J, Limsuwan A, Sweeney M, Rubin LJ, Yuan JX (2001) Upregulated TRP and enhanced capacitative $\mathrm{Ca}^{2+}$ entry in human pulmonary artery myocytes during proliferation. Am J Physiol Heart Circ Physiol 280:H746-H755.

Gomez TM, Zheng JQ (2006) The molecular basis for calcium-dependent axon pathfinding. Nat Rev Neurosci 7:115-125.

Goto H, Tomono Y, Ajiro K, Kosako H, Fujita M, Sakurai M, Okawa K, Iwamatsu A, Okigaki T, Takahashi T, Inagaki M (1999) Identification of a novel phosphorylation site on histone $\mathrm{H} 3$ coupled with mitotic chromosome condensation. J Biol Chem 274:25543-25549.

Greka A, Navarro B, Oancea E, Duggan A, Clapham DE (2003) TRPC5 is a regulator of hippocampal neurite length and growth cone morphology. Nat Neurosci 6:837-845.

Grynkiewicz G, Poenie M, Tsien RY (1985) A new generation of $\mathrm{Ca}^{2+}$ indicators with greatly improved fluorescence properties. J Biol Chem 260:3440-3450.

Hinks GL, Franklin RJ (1999) Distinctive patterns of PDGF-A, FGF-2, IGF-1 and TGF- $\beta 1$ gene expression during remyelination of experimentally-induced spinal cord demyelination. Mol Cell Neurosci 14:153-168.

Jacobs EC, Pribyl TM, Feng JM, Kampf K, Spreur V, Campagnoni C, Colwell CS, Reyes SD, Martin M, Handley V, Hiltner TD, Readhead C, Jacobs RE, Messing A, Fisher RS, Campagnoni AT (2005) Region-specific myelin pathology in mice lacking the golli products of the myelin basic protein gene. J Neurosci 25:7004-7013.

Jacobs E, Reyes S, Campagnoni CW, Givogri IM, Kampf K, Handley V, Spreuer V, Fisher RS, Macklin W, Campagnoni AT (2009) Targetted overexpression of a golli-myelin basic protein isoform to oligodendrocytes results in aberrant oligodendrocyte maturation and myelination. ASN Neuro 1.pii:e00017.

Kakita A, Goldman JE (1999) Patterns and dynamics of SVZ cell migration in the postnatal forebrain: monitoring living progenitors in slice preparations. Neuron 23:461-472.

Kim SJ, Kim YS, Yuan JP, Petralia RS, Worley PF, Linden DJ (2003) Activa- tion of the TRPC1 cation channel by metabotropic glutamate receptor mGluR1. Nature 426:285-291.

Landry CF, Ellison JA, Pribyl TM, Campagnoni C, Kampf K, Campagnoni AT (1996) Myelin basic protein gene expression in neurons: developmental and regional changes in protein targeting within neuronal nuclei, cell bodies, and processes. J Neurosci 16:2452-2462.

Landry CF, Pribyl TM, Ellison JA, Givogri MI, Kampf K, Campagnoni CW, Campagnoni AT (1998) Embryonic expression of the myelin basic protein gene: identification of a promoter region that targets transgene expression to pioneer neurons. J Neurosci 18:7315-7327.

Liao Y, Erxleben C, Yildirim E, Abramowitz J, Armstrong DL, Birnbaumer L (2007) Orai proteins interact with TRPC channels and confer responsiveness to store depletion. Proc Natl Acad Sci U S A 104:4682-4687.

Mallon BS, Shick HE, Kidd GJ, Macklin WB (2002) Proteolipid promoter activity distinguishes two populations of NG2-positive cells throughout neonatal cortical development. J Neurosci 22:876-885.

Manders EMM, Verbeek FJ, Aten JA (1993) Measurement of co-localization of objects in dual-color confocal images. J Microsc 169:375-382.

Martin M, Reyes SD, Hiltner TD, Givogri MI, Tyszka JM, Fisher R, Campagnoni AT, Fraser SE, Jacobs RE, Readhead C (2007) T(2)-weighted $\mu \mathrm{MRI}$ and evoked potential of the visual system measurements during the development of hypomyelinated transgenic mice. Neurochem Res 32:159-165.

Michel S, Itri J, Colwell CS (2002) Excitatory mechanisms in the suprachiasmatic nucleus: the role of AMPA/KA glutamate receptors. J Neurophysiol 88:817-828.

Nilius B, Owsianik G, Voets T, Peters JA (2007) Transient receptor potential cation channels in disease. Physiol Rev 87:165-217.

Noble M, Murray K, Stroobant P, Waterfield MD, Riddle P (1988) Plateletderived growth factor promotes division and motility and inhibits premature differentiation of the oligodendrocyte/type-2 astrocyte progenitor cell. Nature 333:560-562.

Paez PM, Spreuer V, Handley V, Feng JM, Campagnoni C, Campagnoni AT (2007) Increased expression of golli myelin basic proteins enhances calcium influx into oligodendroglial cells. J Neurosci 27:12690-12699.

Paez PM, Fulton DJ, Spreur V, Handley V, Campagnoni CW and Campagnoni AT (2009a) Regulation of store-operated and voltage-operated $\mathrm{Ca}^{2+}$ channels in the proliferation and death of oligodendrocyte precursor cells by Golli proteins. ASN Neuro 1.pii:e00003.

Paez PM, Fulton DJ, Spreuer V, Handley V, Campagnoni CW, Macklin WB, Colwell C, Campagnoni AT (2009b) Golli myelin basic proteins regulate oligodendroglial progenitor cell migration through voltage-gated $\mathrm{Ca}^{2+}$ influx. J Neurosci 29:6663-6676.

Parekh AB, Putney JW Jr (2005) Store-operated calcium channels. Physiol Rev 85:757-810.

Paz Soldán MM, Warrington AE, Bieber AJ, Ciric B, Van Keulen V, Pease LR, Rodriguez M (2003) Remyelination-promoting antibodies activate distinct $\mathrm{Ca}^{2+}$ influx pathways in astrocytes and oligodendrocytes: relationship to the mechanism of myelin repair. Mol Cell Neurosci 22:14-24.

Pribyl TM, Campagnoni CW, Kampf K, Kashima T, Handley VW, McMahon J, Campagnoni AT (1993) The human myelin basic protein gene is included within a 179-kilobase transcription unit: expression in the immune and central nervous systems. Proc Natl Acad Sci U S A 90:10695-10699.

Putney JW Jr (1993) Excitement about calcium signaling in inexcitable cells. Science 262:676-678.

Putney JW Jr (1999) TRP, inositol 1,4,5-trisphosphate receptors, and capacitative calcium entry. Proc Natl Acad Sci U S A 96:14669-14671.

Raff MC, Lillien LE, Richardson WD, Burne JF, Noble MD (1988) Platelet-derived growth factor from astrocytes drives the clock that times oligodendrocyte development in culture. Nature 333:562-565.

Reyes SD, Campagnoni AT (2002) Two separate domains in the golli myelin basic proteins are responsible for nuclear targeting and process extension in transfected cells. J Neurosci Res 69:587-596.

Riccio A, Medhurst AD, Mattei C, Kelsell RE, Calver AR, Randall AD, Benham CD, Pangalos MN (2002) mRNA distribution analysis of human TRPC family in CNS and peripheral tissues. Brain Res Mol Brain Res 109:95-104.

Riccio A, Li Y, Moon J, Kim KS, Smith KS, Rudolph U, Gapon S, Yao GL, Tsvetkov E, Rodig SJ, Van't Veer A, Meloni EG, Carlezon WA Jr, Bolshakov VY, Clapham DE (2009) Essential role for TRPC5 in amygdala function and fear-related behavior. Cell 137:761-772. 
Simpson PB, Russell JT (1997) Role of sarcoplasmic/endoplasmicreticulum $\mathrm{Ca}^{2+}$-ATPases in mediating $\mathrm{Ca}^{2+}$ waves and local $\mathrm{Ca}^{2+}$ release microdomains in cultured glia. Biochem J 325:239-347.

Simpson PB, Challiss RA, Nahorski SR (1995) Neuronal $\mathrm{Ca}^{2+}$ stores: activation and function. Trends Neurosci 18:299-306.

Simpson PB, Mehotra S, Lange GD, Russell JT (1997) High density distribution of endoplasmic reticulum proteins and mitochondria at specialized $\mathrm{Ca}^{2+}$ release sites in oligodendrocyte processes. J Biol Chem 272:22654-22661.

Smyth JT, Dehaven WI, Jones BF, Mercer JC, Trebak M, Vazquez G, Putney JW Jr (2006) Emerging perspectives in store-operated $\mathrm{Ca}^{2+}$ entry: roles of Orai, Stim and TRP. Biochim Biophys Acta 1763:1147-1160.

Strübing C, Krapivinsky G, Krapivinsky L, Clapham DE (2003) Formation of novel TRPC channels by complex subunit interactions in embryonic brain. J Biol Chem 278:39014-39019.

Suzumura A, Bhat S, Eccleston PA, Lisak RP, Silberberg DH (1984) The isolation and long-term culture of oligodendrocytes from newborn mouse brain. Brain Res 324:379-383.

Sweeney M, Yu Y, Platoshyn O, Zhang S, McDaniel SS, Yuan JX (2002a) Inhibition of endogenous TRP1 decreases capacitative $\mathrm{Ca}^{2+}$ entry and attenuates pulmonary artery smooth muscle cell proliferation. Am J Physiol Lung Cell Mol Physiol 283:L144-L155.

Sweeney M, McDaniel SS, Platoshyn O, Zhang S, Yu Y, Lapp BR, Zhao Y, Thistlethwaite PA, Yuan JX (2002b) Role of capacitative $\mathrm{Ca}^{2+}$ entry in bronchial contraction and remodeling. J Appl Physiol 92:1594-1602.

Walsh CM, Doherty MK, Tepikin AV, Burgoyne RD (2010) Evidence for an interaction between Golli and STIM1 in store-operated calcium entry. Biochem J 430:453-460.

Wang J, Shimoda LA, Sylvester JT (2004) Capacitative calcium entry and TRPC channel proteins are expressed in rat distal pulmonary arterial smooth muscle. Am J Physiol Lung Cell Mol Physiol 286:L848-L858.

Wang W, O'Connell B, Dykeman R, Sakai T, Delporte C, Swaim W, Zhu X, Birnbaumer L, Ambudkar IS (1999) Cloning of Trplbeta isoform from rat brain: Immunodetection and localization of the endogenous Trp1 protein. Am J Physiol 276:C969-C979.

Weerth SH, Holtzclaw LA, Russell JT (2007) Signaling proteins in raft-like microdomains are essential for $\mathrm{Ca}^{2+}$ wave propagation in glial cells. Cell Calcium 41:155-167.

Wei Y, Yu L, Bowen J, Gorovsky MA, Allis CD (1999) Phosphorylation of histone $\mathrm{H} 3$ is required for proper chromosome condensation and segregation. Cell 97:99-109.

Woods NM, Cuthbertson KS, Cobbold PH (1986) Repetitive transient rises in cytoplasmic free calcium in hormone-stimulated hepatocytes. Nature 319:600-602.

Wu D, Huang W, Richardson PM, Priestley JV, Liu M (2008) TRPC4 in rat dorsal root ganglion neurons is increased after nerve injury and is necessary for neurite outgrowth. J Biol Chem 283:416-426.

$\mathrm{Xu}$ SZ, Beech DJ (2001) TrpC1 is a membrane-spanning subunit of storeoperated $\mathrm{Ca}^{2+}$ channels in native vascular smooth muscle cells. Circ Res 88:84-87.

Zitt C, Halaszovich CR, Lückhoff A (2002) The TRP family of cation channels: probing and advancing the concepts of receptor-activated calcium entry. Prog Neurobiol 66:243-264. 